NASA/TM-1999-208895

\title{
Ice Accretion Calculations for a Commercial Transport Using the LEWICE3D, ICEGRID3D and CMARC Programs
}

Colin S. Bidwell

Lewis Research Center, Cleveland, Ohio

David Pinella and Peter Garrison

AeroLogic, Los Angeles, California 
Since its founding, NASA has been dedicated to the advancement of aeronautics and space science. The NASA Scientific and Technical Information (STI) Program Office plays a key part in helping NASA maintain this important role.

The NASA STI Program Office is operated by Langley Research Center, the Lead Center for NASA's scientific and technical information. The NASA STI Program Office provides access to the NASA STI Database, the largest collection of aeronautical and space science STI in the world. The Program Office is also NASA's institutional mechanism for disseminating the results of its research and development activities. These results are published by NASA in the NASA STI Report Series, which includes the following report types:

- TECHNICAL PUBLICATION. Reports of completed research or a major significant phase of research that present the results of NASA programs and include extensive data or theoretical analysis. Includes compilations of significant scientific and technical data and information deemed to be of continuing reference value. NASA's counterpart of peerreviewed formal professional papers but has less stringent limitations on manuscript length and extent of graphic presentations.

- TECHNICAL MEMORANDUM. Scientific and technical findings that are preliminary or of specialized interest, e.g., quick release reports, working papers, and bibliographies that contain minimal annotation. Does not contain extensive analysis.

- CONTRACTOR REPORT. Scientific and technical findings by NASA-sponsored contractors and grantees.
- CONFERENCE PUBLICATION. Collected papers from scientific and technical conferences, symposia, seminars, or other meetings sponsored or cosponsored by NASA.

- SPECIAL PUBLICATION. Scientific, technical, or historical information from NASA programs, projects, and missions, often concerned with subjects having substantial public interest.

- TECHNICAL TRANSLATION. Englishlanguage translations of foreign scientific and technical material pertinent to NASA's mission.

Specialized services that complement the STI Program Office's diverse offerings include creating custom thesauri, building customized data bases, organizing and publishing research results ... even providing videos.

For more information about the NASA STI Program Office, see the following:

- Access the NASA STI Program Home Page at http://www.sti.nasa.gov

- E-mail your question via the Internet to help@sti.nasa.gov

- Fax your question to the NASA Access Help Desk at (301) 621-0134

- Telephone the NASA Access Help Desk at (301) 621-0390

- Write to:

NASA Access Help Desk

NASA Center for AeroSpace Information 7121 Standard Drive

Hanover, MD 21076 
NASA/TM-1999-208895

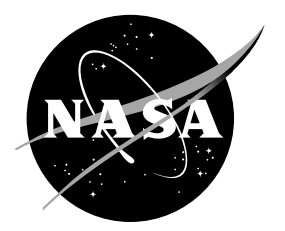

\section{Ice Accretion Calculations for a Commercial Transport Using the LEWICE3D, ICEGRID3D and CMARC Programs}

Colin S. Bidwell

Lewis Research Center, Cleveland, Ohio

David Pinella and Peter Garrison

AeroLogic, Los Angeles, California

Prepared for the

37th Aerospace Sciences Meeting \& Exhibit

sponsored by the American Institute of Aeronautics and Astronautics

Reno, Nevada, January 11-14, 1999

National Aeronautics and

Space Administration

Lewis Research Center 
Available from

NASA Center for Aerospace Information 7121 Standard Drive

Hanover, MD 21076

Price Code: A03
National Technical Information Service 5285 Port Royal Road Springfield, VA 22100 Price Code: A03 


\title{
Ice Accretion Calculations For a Commercial Transport Using the LEWICE3D, ICEGRID3D and CMARC Programs
}

\author{
Colin S. Bidwell \\ National Aeronautics and Space Administration \\ Lewis Research Center \\ Cleveland, Ohio 44135 \\ David Pinella \\ Peter Garrison \\ AeroLogic \\ Los Angeles, CA
}

\section{SUMMARY}

Collection efficiency and ice accretion calculations were made for a commercial transport using the NASA Lewis LEWICE3D ice accretion code, the ICEGRID3D grid code and the CMARC panel code. All of the calculations were made on a Windows 95 based personal computer. The ice accretion calculations were made for the nose, wing, horizontal tail and vertical tail surfaces. Ice shapes typifying those of a 30 minute hold were generated. Collection efficiencies were also generated for the entire aircraft using the newly developed unstructured collection efficiency method. The calculations highlight the flexibility and cost effectiveness of the LEWICE3D, ICEGRID3D, CMARC combination.

NOMENCLATURE

$\begin{array}{ll}\text { AAOA } & \text { Aircraft-angle-of-attack, degrees } \\ \mathrm{d} & \text { Droplet diameter, } \mu \mathrm{m} \\ \mathrm{HTC} & \text { Convective heat transfer coefficient, } \mathrm{W} / \mathrm{m}^{2} / \mathrm{K} \\ \mathrm{LWC} & \text { Liquid Water Content, } \mathrm{g} / \mathrm{m}^{3} \\ \mathrm{MVD} & \text { Median Volume Diameter, } \mu \mathrm{m} \\ \mathrm{W} & \text { Mass flow, } \mathrm{kg} / \mathrm{s} \\ \beta & \text { Collection efficiency } \\ \alpha & \text { Angle-of-attack, degrees } \\ \theta & \text { Radial angle around inlet lip measured from the upper inlet lip, degrees } \\ & \\ & \\ & \text { American Institute of Aeronautics and Astronautics }\end{array}$




\section{INTRODUCTION}

The design of ice protection systems for new and derivative aircraft has typically been an expensive and cumbersome procedure. The design work has typically involved a hodgepodge of methodologies including 2-Dimensional (2D) experimental data, 2D trajectory and ice accretion codes, wind tunnel tests and flight tests. Difficulties can arise in using any of the methods. Experimental data may not exist for the geometry or conditions of interest. Applying $2 \mathrm{D}$ analytical methods to aircraft wing and tail configurations involves corrections for sweep, taper, up-wash, down-wash, twist, etc. many of which are not exact. Wind tunnel tests can involve scaling issues if sub-scale models are used or blockage and configuration problems if full scale models are used. Where full configuration, full scale effects are important (e.g., fuselage mounted inlets and radomes, ducts and flaps) the above methods cannot be employed with any confidence. In these cases expensive full scale flight testing has typically been required.

These problems have led to the development over the last 15 years of a series of 3-Dimensional (3D) droplet trajectory codes and ice accretions codes (ref. 1-5). These methods involve the use of various 3D flow codes and droplet trajectory codes which can aid the designer in determining where and to what level ice protection is needed. The increased sophistication of these codes along with the decreased cost of computing cycles has allowed the designer to get elegant, cheap solutions for complex configurations early on in the design cycle decreasing the overall development costs of these systems.

This paper outlines what is probably the least expensive methodology available to the designer of the ice protection system. The calculations presented herein were made using the LEWICE3D ice accretion code (ref. 3), the ICEGRID3D unstructured cartesian grid code (ref. 6), and the CMARC 3D panel code (ref. 7-9) on a personal computer. These tools can be used by experienced users to generate results for full scale configurations in several days on a Personal Computer (PC).

The configuration and conditions for the study were chosen to exemplify those of a typical ice protection system design. Calculations were made for the wing, nose and tail of a commercial transport in a hold condition. Results for pressure coefficient, collection efficiency, heat transfer, and ice shapes on these surfaces are presented. In addition results for the collection efficiency of the entire aircraft using the new unstructured collection efficiency method are presented.

\section{ANALYTICAL METHOD}

The icing calculation required a three step process. The ICEGRID3D code was used to generate the grid for the droplet trajectory calculations. The CMARC code was used to generate the velocities on this grid and to generate the surface velocities needed in the LEWICE3D code. The LEWICE3D code then used the panel model, surface velocity information and the grid to make the ice accretion calculations. All of the calculations were made on a Pentium II PC with a single $400 \mathrm{MHZ}$ CPU and $384 \mathrm{MB}$ of RAM. 


\section{A. ICEGRID3D}

The ICEGRID3D code was developed at Lewis Research Center by Bidwell and Coirier (ref. 6) specifically for the task of optimizing droplet trajectory calculations in the LEWICE3D code. The program automatically produces grids which are optimal for droplet trajectory calculations hence reducing the required effort to produce a "good" droplet trajectory grid. The program also produces a minimum of grid points which reduces the panel code calculation times. The program requires the surface geometry and an input file describing the grid volume and refinement parameters. The code refines the grid near regions of interest which can include; parts of the geometry, lines, and points. The code is similar to an oct-tree method (ref. 10) in that it recursively divides the original grid volume until the refinement criteria for each cell has been met. The code will not refine cells internal to the geometry. The code is different from most oct-tree methods in that the grid volume is allowed to be multiple-skewed, multi-blocked, plus different refinement functions can be used in any direction. This last feature is where the code differs from the oct-tree methods in that it allows a given cell to be divided into 8,4 or 2 cells depending on the refinement function instead of the oct-tree method which divides a cell into 8 cells if the refinement is required. This results in grids with much fewer cells for cases where grid requirements are disparate in the different directions (e.g. swept wings which have a much smaller cell size requirement in the chord-wise direction than in the spanwise direction).

\section{B. CMARC}

CMARC is a first order 3D potential flow panel code (ref. 7) based on the PMARC (ref. 8) and VSAERO codes (ref. 9). Geometries are represented as quadrilaterals which have constant doublet and source distribution. The formulation used in CMARC results in a solution that is second order accurate allowing for accurate flow solutions with fewer panels and less CPU time than other first order methods. The code can generate solutions for internal and external compressible flows and can handle very large problems ( 10,000 panels).

\section{LEWICE3D}

The LEWICE3D grid based code incorporates droplet trajectory, heat transfer and ice shape calculation into a single computer program (ref. 3). The code can handle generic multiblock structured grid based flow solutions, unstructured grid based flow solutions, simple cartesian grids with surface patches, and adaptive grids with surface patches. The latter two methods allow the use of generic panel code input which is a computationally efficient method for generating ice shapes.The code can handle overlapping and internal grids and can handle multiple planes of symmetry. Calculations of arbitrary streamlines and trajectories are possible. The code has the capability to calculate tangent trajectories and impingement efficiencies for single droplets or droplet distributions. Ice accretions can be calculated at arbitrary regions of interest in either a surface normal or tangent droplet trajectory direction.

The methodology used in the LEWICE3D analysis can be broken into six basic steps for each section of interest at each time step. In the first step, the flow field is generated by the user. 
Second, surface streamlines are calculated. The surface streamline analysis uses a variable step size fourth-order Runge-Kutta integration scheme developed by Bidwell (ref. 3). Third, tangent trajectories are calculated at the region of interest. An array of particles is released between the tangent trajectories in the fourth step. These impacting particles are used to calculate collection efficiency as a function of surface position. The droplet trajectory analysis is basically that of Hillyer Norment (ref. 1) with modifications by Bidwell (ref. 3). At the heart of the droplet trajectory analysis is the variable step predictor-corrector integration scheme by Krogh (ref. 11). The fifth step involves interpolating or extrapolating the collection efficiencies onto the streamlines. In the sixth step the ice accretion for the streamline is calculated. The ice accretion model is basically that of the LEWICE2D code applied along surface streamlines (ref. 12,13).

An unstructured collection efficiency calculation method was added to the LEWICE3D code recently and results using the method are presented. This method, which was developed by Bidwell, was developed as a simple, efficient means of generating collection efficiency maps for large complex surfaces. The user specifies an upstream release region (a simple vertical quadrilateral) which encompasses the region of interest and a minimum cell size. The region is then recursively subdivided (trajectories are released at the node points of the subdivided region) in areas where particle trajectories become close or hit the body until the minimum cell size requirement is met. The collection efficiency for each panel is then equal to the number of particles that hit the panel times the area of the minimum upstream cell size divided by the area of the panel. The method efficiently incorporates the tangent droplet trajectory search and the collection efficiency calculation into one step. Although the method is more computationally expensive than traditional methods (many more droplet trajectory integrations are required), it is not prohibitive. Large problems can still be handled with overnight runs on a PC (4-20 hours). The unstructured method has the advantage that large, complex problems are easier to setup than for more traditional methods. Is is also advantageous in that the method can handle complex geometries (inlet lip-duct problems, highly separated flows, multi-element) that other more traditional codes may not handle. It can also find impingement regions (multi-element) that other codes may miss if not expected.

\section{CONFIGURATION}

The conditions and geometry for the analysis were chosen to typify a commercial transport in a hold condition. The configuration used in the analysis, which is similar to a Boeing 737 airplane, was chosen to be consistent with those of a wind tunnel model used at Langley Research Center for iced stability and control measurements (ref. 14,15). The coordinates for this model were obtained from Langley Research Center. A hold condition was chosen because it was an important design point for the ice protection systems on a commercial transport.

The aircraft model was a simplified version of the Boeing 737 airplane. The engine nacelles and engine pylons were not included in the flow model. The wings were modeled using a single element model with retracted flaps and slats. The deletion of these features from the aircraft should not be deemed too severe, considering the position of the engines and the position of the flaps and slats in a typical hold condition.

A single flight condition was chosen for the study. The flight condition for the analysis was; aircraft-angle-of-attack (AAOA), 4 degrees, altitude, 4572 meters, airspeed, $135 \mathrm{~m} / \mathrm{s}$, static 
temperature, $259 \mathrm{~K}$, icing time, 30 minutes, liquid water content (LWC), $0.51 \mathrm{~g} / \mathrm{m}^{3}$, and median volume diameter (MVD), $20 \mu \mathrm{m}$.

The computational parameters were chosen from experience, correlations and the desire to limit the computational resources required. A single drop size and icing time step were chosen for the study. A LEWICE roughness parameter of $0.5 \mathrm{~mm}$ was used for all of the cases (ref. 12). The calculations were made at six spanwise stations on the wing, three spanwise stations on the horizontal and vertical tails, and a single vertical cut on the nose of the aircraft. In the wing analysis, three spanwise stations were distributed on the outer portion of the wing and three were distributed on the inner portion of the wing. The break in leading edge sweep angle near the $30 \%$ span location denotes the boundary between the outer and inner portions of the wing. The spanwise cuts were located at the 10\%, 50\% and 90\% locations for the inner and outer parts of the main wings, the horizontal tail, and the vertical tails. The $10 \%$ and $90 \%$ span stations were chosen as conservative limits for the LEWICE3D methodology. Outside of these limits the spanwise gradients can be large and the strip assumptions built into the LEWICE3D methodology can be violated.

\section{ANALYSIS}

Surface velocity, heat transfer, collection efficiency, and ice shapes results are presented for the commercial airplane at various stations around the wing, horizontal tail, vertical tail and fuselage nose. Ice shape calculations were made for a singe condition representing a hold condition. Discussions of the panel model, grids, the LEWICE3D program parameters, and of the individual analysis are given below.

Figure 1 shows the CMARC panel model and the surface cuts for the analysis. A halfplane model was employed because a zero degree yaw angle was used in the analysis. The panel model contained 6545 panels and required 54 minutes of CPU time on the 400 MHZ Pentium II PC to solve. These panels were concentrated near the leading edge of the wing, horizontal and vertical tails and the aircraft nose to generate a "good" ice shape calculation. To obtain a reasonable representation of the ice shapes approximately 15 to 20 chord-wise panels are required within the impingement limits. This constraint resulted in panel models for the wing, and horizontal and vertical tails which had approximately 100 chord-wise panels.

Non-standard settings for the CMARC parameters RFF, RCORES, and RCOREW were used to generate the off-body velocities. Values of 25., 0.0002 and 0.0002 were used respectively (ref. 7). A relatively large value of RFF was used because of the very small panels used near the leading edge of the wing, the tail, and the nose of the aircraft. Very small values of RCORES and RCOREW (essentially zero) were used to bypass the singularity "fix" used in the velocity subroutines because it did not work very well. The singularities were handled in a more consistent manner in the post processing program VELCOND developed by Bidwell. This program replaces the off-body velocities near the surface and internal to the surface with surface velocities interpolated from the panel center points. This velocity "conditioning" was key in generating smooth and consistent results. 
The off-body velocities were generated using the CMVSCAN post processor developed by AeroLogic (ref. 7). The post processor used the flow-field solution generated by CMARC to generate velocities at the ICEGRID3D grid points. Separate calculations were done for each of the ICEGRID3D blocks. These results were combined into a single multi-block grid file for input into LEWICE3D. The off-body calculations for the 3,107,543 points required approximately 45 hours of CPU time on the 400 MHZ Pentium II PC.

The grid blocking structure is shown in fig. 2a-c. A total of 9 ICEGRID3D grid blocks were used in the grid. Each of the blocks were calculated separately and combined before input into the LEWICE3D program. These 9 blocks required approximate 48 hours of CPU time on the $400 \mathrm{MHZ}$ Pentium II PC to generate. The multi-block structure was used to minimize the total number of points used, the time required to re-work a grid if necessary, and the overall ICEGRID3D calculation time. The multiple-skewed feature of the ICEGRID3D grid blocking scheme allows the grid block to be aligned with the dihedral and sweep of the wing or tail to minimize the number of grid points required, but for cases with large sweep or dihedral change or elements with different sweep a single grid block is not optimal. In these cases, multiple blocks were used with separate blocks tailored for each element of interest. The use of separate blocks also reduces the time to generate a new grid if a region needs to be re-worked because only the grid block associated with the region of interest needs to be recalculated. Breaking the problem into smaller blocks also reduces the memory required for ICEGRID3D and allows the use of multiple machines (i.e. one for each grid) to decrease the turnaround time.

Figure 2 reveals the overall blocking strategy. One can see that the grid blocks are overlapping and have various sizes, and skewness. Three grid blocks were used for the wing to handle the changes in sweep and dihedral of the wing and to handle the transition into the fuselage grid blocks. Transition grids between airfoils and the fuselage were needed for the wing and tails sections because the airfoil surfaces had different grid resolution requirements then the fuselage. The wings and tails required very few span-wise planes but required many chord-wise points and points normal to the surface. The fuselage required the same grid spacing in all three directions and hence typically required more points. The three wing grid blocks enveloped the area in front of the wing to just aft of the wing. A single grid block was used for the outboard portion of the horizontal tail. The vertical tail required two blocks to accommodate the change in sweep. A single grid block was used for the fuselage grid and the transitions from the horizontal and vertical tail grids. This fuselage grid block and all of the tail blocks extended from aft of the wing to aft of the plane. Two blocks were used to handle the remainder of the fuselage; a block extending from the aircraft wind screen to forward of the aircraft, and a block extending from aft of the wing forward to the wind screen.

The grid resolution for various regions around the aircraft are shown in fig. 3. The maximum cell size for the grids was $0.813 \mathrm{~m}$ in all three coordinate directions. For the nose of the aircraft a minimum cell size of $0.003 \mathrm{~m}$ was used. The same cell size requirements were used in the all three coordinate directions for the nose. For the horizontal and vertical tail grids the minimum chord-wise and surface normal spacing were $0.003 \mathrm{~m}$. The minimum spanwise spacing for the horizontal and vertical tail was $0.102 \mathrm{~m}$. For the wing the minimum spanwise spacing was 0.203 $\mathrm{m}$. The wing had a minimum chord-wise and surface normal spacing of $0.002 \mathrm{~m}$. A minimum cells size of $0.051 \mathrm{~m}$ was used in all three coordinate directions for the mid-fuselage block. 
The philosophy behind the surface paneling and grid generation is to pack panels and points where the trajectories are going to hit the surface and to use few panels and points away from the impact regions. The grid cell sizes should be consistent with the panel sizes in the impact regions. It does no good to put a lot of grid points in a region with poor paneling or vice-versa. In cases where the particles travel close to the body for extended lengths (e.g. the underside of the wing at higher angles-of-attack) or where trajectories need to be calculated accurately along the fuselage to some region of interest (e.g. radome) smaller panels and grid cell sizes may be required.

Figure 3 shows this philosophy applied to the different elements of the aircraft. For the wing, impingement was expected on the underside of the wing due to the configuration of the AAOA. Grid points and panels were packed around the leading edge and underside of the wing. A small grid spacing was used for a large portion of underside of the wing to carry the tangent trajectories aft accurately without hitting the body erroneously. For the vertical and horizontal tail, the impingement regions were more towards the leading edge and more symmetric due to the lower effective angle-of-attack; hence the grids points, and surface panels are packed more symmetrically around these regions. A relatively large spacing was used for the mid-fuselage grid because no impingement was expected. The nose grid reflects the impingement expected on the nose of the aircraft. The blunt nature of the nose tends to throw particles out away from the body if they do not hit, resulting in a shadow zone around the entire fuselage aft of the nose. For this reason only a small region around the nose was refined.

The icing analysis for the commercial aircraft are shown in fig. 4-23. The section profiles and coefficient of pressure distributions were generated along the flow directions. The collection efficiency, heat transfer coefficient and ice shape profiles were generated in a direction normal to the leading edge. Each section-of-interest required approximately 2 minutes of CPU time on the $400 \mathrm{MHZ}$ Pentium II PC. The overall collection efficiency results shown in fig. 23 involved the calculation of approximately 340,000 trajectories and required about 25 hours of CPU time.

The computational results for the wing are shown in fig. 4-8. Figure 4 depicts the airfoil section at the six spanwise stations where the analysis was done. In general the wing was complex, having taper, twist and section variation.

Figure 5 shows the coefficient of pressure distribution at each of the six spanwise stations. The section lift coefficient increases as the wing root is approached on the outboard section of the wing due to wing twist and up-wash effects. The effective angle-of-attack for the inner five sections is relatively constant. The leading edge coefficient of pressure gradient decreases (i.e. the peaks are more rounded) as the root is approached due to the increase in chord and sweep.

Figure 6 shows the heat transfer coefficient distribution results for the wing. In general, as the wing root was approached the stagnation heat transfer and the peak heat transfer on both the upper and lower surfaces decreased. Additionally the laminar-turbulent transition points on the upper and lower surfaces moved further aft as the spanwise location moved towards the wing root. These effects are due to the increase in chord and sweep angle as the root was approached and the corresponding decrease in leading edge velocity gradients (and the associated coefficient of pres- 
sure). The heat transfer coefficient distribution is calculated from the surface velocity distribution in the integral boundary layer technique employed, hence, trends seen in the heat transfer distribution can be gleaned from the coefficient of pressure distribution (i.e where there are large gradients in the coefficients of pressure there are high heat transfer coefficients).

The collection efficiency results for the wing are shown in fig. 7. In general the shapes of the collection efficiency curves were similar except for the two most inboard sections. The shapes are similar for the four outboard sections because the airfoil sections employed at these locations were similar. The inner two sections have blunter sections, hence the collection efficiency curves have wider more rounded peaks. The curves show that the majority of the water is hitting on the underside of the wing. This was due to the high AAOA (4 degrees) used in the study. In general the maximum collection efficiency decreased as the root was approached because of the increase in chord of the wing.

The calculated ice shapes for the wing are shown in fig. 8. Due to the mixed or glaze nature of the ice (i.e. there was significant run-back at the leading edge) the ice shapes follow the trends set by the heat transfer coefficient described above. When there is more water impinging than can freeze at the leading edge, the amount of ice formed is determined by the heat transfer at the leading edge. The result being that the ice shape thickness distribution and the resulting ice shape take on characteristics of the heat transfer coefficient distribution. From the figures it can be seen that the ice thickness at the stagnation zone decreases as the root is approached due to the decreasing stagnation heat transfer. Also the maximum thickness on the upper and lower surfaces moves further aft as the root is approached due to the aft movement of the boundary layer transition point.

Results for the horizontal tail are presented in fig. 9-13. The airfoil sections for the tail are shown in figure 9. The horizontal tail element was of a more simpler construction than the wing, having no twist and constant sweep, section and taper ratio.

Figures 10, 11 show the coefficient of pressure and heat transfer coefficient distributions respectively. From the coefficient of pressure distribution a decrease in angle-of-attack can be seen as the root is approached due to down-wash. This results in a slight shift in the stagnation region, and hence heat transfer coefficient distribution, towards the upper surface. Also evident is a decrease in the leading edge pressure gradient due to the increase in chord. This results in a decrease in the stagnation heat transfer and the maximum heat transfer on both the upper lower surfaces as the root is approached.

Collection efficiency distributions are shown in fig. 12 for the horizontal tail.The curves have similar shapes and show a decrease in maximum collection efficiency as the wing root is approached due to the increase in chord. Also evident is a shift in the impingement region towards the upper side surface of the horizontal tail. This can be attributed to the decrease in angle-ofattack as the root is approached, due to the wing down-wash.

The calculated ice shapes for the horizontal tail are shown in fig. 13. The results for the horizontal tail are similar to those for the wing. From fig. 13, a decrease in the stagnation region ice thickness from tip to root can be seen due to the decrease in stagnation heat transfer. Also, the 
maximum thickness on the upper and lower surfaces moves further aft as the root is approached due to the aft movement of the boundary layer transition point. There is also a slight shift in the ice shape towards the upper surface as the root is approached due to the decreased angle-of-attack associated with the wing down-wash.

Figures 14-18 depict the icing analysis for the vertical tail. The vertical tail airfoil sections are shown in fig. 14. The vertical tail was of a simple construction containing symmetric sections of a similar airfoil type which varied in chord length due to the taper and the change in leading edge sweep angle.

The coefficient of pressure and heat transfer coefficient distributions for the vertical tail are shown in fig. 15 and 16. As for the wing and the horizontal tail the leading edge pressure coefficient of pressure gradient decreases and the stagnation heat transfer coefficient and maximum heat transfer coefficient on the upper and lower surface decrease as the as the fuselage is approached. This is due to the increase in chord and sweep angle as the fuselage is approached. Also noteworthy is a slight discontinuity in the pressure distribution near the leading edge of the outer two spanwise stations. This is due to the coarse geometry definition of the original model. Many points were splined into the leading edge region from a very few original leading edge points (3-5 points) and spanwise points. This can cause wrinkles and slope discontinuities which show up as discontinuities in the pressure distribution.

Collection efficiency distributions for the vertical tail are shown in fig. 17. The maximum collection efficiency decreases and the impingement limits increase as the fuselage is approached due to both the increase in chord and the increase in sweep angle. The maximum collection for the outer two sections-of-interest were closer than expected. This was due to a deficiency in the grid density at the outer portion of the vertical tail. Evidence of insufficient grid spacing include flattened or in extreme cases dips in the collection efficiency curve near the maximum.

The ice shapes for the vertical tail are shown in fig. 18. The resulting ice shapes show the same trends as the wing and horizontal tail. The maximum ice thickness decreases and the point at which the maximum ice thickness occurs moves further aft as the wing root is approached.

The icing analysis for the fuselage nose is shown in fig. 19-22. Only a single vertical ice shape was calculated for the nose. Other radial cuts at the nose could have been generated but the results would have been similar. The nose of the aircraft was very blunt, much like a large sphere. This led to a very small leading edge coefficient of pressure gradient and hence to small values of heat transfer coefficients in the stagnation region. The maximum collection efficiency for the nose was also very small ( .20) due to the large, blunt nature of the nose. The ice shape which is shown in fig. 22 is very thin with the maximum thickness point being relatively far back on both the upper and lower surfaces. This is due to the very low stagnation heat transfer and the large laminar flow region at the leading edge of the nose.

Figures 23a-f depict the overall picture of the collection efficiency for the airplane. The collection efficiency for the aircraft was generated using the new unstructured collection efficiency method developed by Bidwell. The calculations, although computationally expensive, give a much broader picture of the collection efficiency characteristics of the airplane. Fig. 23a shows 
the aircraft along with the unstructured droplet trajectory release point grid used to generate the collection efficiency map. The grid shows the release points of the trajectories used in the unstructured calculation, hence, it is located approximately an aircraft length ahead of the body. Each of the grid nodes represent a particle release point used in the unstructured droplet trajectory iteration. The methodology involves recursively refining the grid around trajectories that are close to or hit the body until a minimum cell size is attained. The result being that the grid is very dense around regions that correspond to areas where the trajectories hit the body. The grid was superimposed on the image to give the analyst insight into the shape and size of the free-stream impingement region.

The free-stream wing impaction region is the long region which extends from the centerline outboard (fig. 23a). The changes in effective angle-of-attack and wing dihedral can be seen in the bowed shape of the wing impingement region. For a fixed section, higher angles-of-attack will result in a downward movement of the impacting droplet trajectory release points. For a fixed angle-of-attack, a higher section will result in an upward movement of the impacting droplet trajectory release points. From fig. 23a, the maximum effective angle-of-attack of the wing can be seen to occur somewhere around the $30 \%$ span location. From fig. 23c the increase in maximum collection efficiency can be seen as the root is approached due to the increase in chord. Also noteworthy is the drop-off in collection efficiency at the wing root due to "shadowing" by the nose of the airplane.

The free-stream impaction region for the horizontal tail is located above the wing impaction region (fig. 23a). It is shorter and bowed downward. The region shows the spanwise changes in dihedral and effective angle-of-attack. From fig. 23a it can be seen that the maximum angle-ofattack for the horizontal tail occurs near the tip. This trend was consistent with that observed for the coefficient of pressure. Similar to the wing case, it can be seen that the maximum collection efficiency drops off as the root is approached due to the increase in chord and that there is a "shadow" zone near the root caused by fuselage (fig. 23d).

The results for the vertical tail are shown in figures $23 \mathrm{a}$ and $23 \mathrm{e}$. The free-stream impaction region for the vertical tail is vertical and occurs along the symmetry plane because the aircraft flow was calculated for a zero yaw angle. From fig. 23e, the fall-off in collection efficiency as the root is approached due to increasing chord and the absence of impingement near the root of the vertical tail due to fuselage "shadowing" can be seen.

Figures $23 \mathrm{a}$ and $23 \mathrm{f}$ depict the results for the aircraft nose. The free-stream impaction region and the impingement region are almost circular due to the blunt spherical nature of the aircraft nose. Because of the size and bluntness of the nose the collection efficiencies are much lower than for the wing and tail elements.

\section{CONCLUSION}

The grid based LEWICE3D, CMARC, ICEGRID3D combination proved to be an inexpensive, flexible, accurate ice protection system design tool. The flow and ice accretion calculations were done quickly, and inexpensively for a range of aircraft elements. 
The ICEGRID3D, CMARC, grid based LEWICE3D combination was, in general, inexpensive to operate for the full aircraft configuration. The grid calculation took approximately 45 hours and the CMARC flow calculations took about 50 hours on the 400 MHZ Pentium II PC computer. The ice accretion calculations required about 2 minutes per section-of-interest. The overall collection efficiency calculations took approximately 25 hours.

In general, the results for coefficient of pressure, heat transfer, collection efficiency and ice shape appear reasonable. The coefficient of pressure followed the correct trends for sweep. The stagnation heat transfer coefficient and the maximum heat transfer coefficient on the upper and lower surfaces decreased with decreasing leading radius of curvature as expected. The location of the maximum heat transfer coefficient also moved further aft with decreasing leading edge radius. The maximum collection efficiency decreased with increased chord and increased sweep angle. Because of the mixed nature of the icing condition used in the study, the ice shapes followed trends set by the heat transfer coefficient. The stagnation ice thickness decreased with increased chord (i.e. decreased leading edge radius). The position of the maximum thickness for both the upper and lower surfaces moved further aft with decreased leading edge radius.

The overall collection efficiency plots generated using the new unstructured collection efficiency method, although relatively computationally expensive, gave greater insight into the icing characteristics of the airplane. From the overall plots the effects of sweep, effective angleof-attack and chord can be seen more easily than using traditional cuts. The "shadowing" effects of the fuselage on the wings and tail are also easily seen from the overall collection efficiency maps. 


\section{REFERENCES}

1. Norment, H.G., "Calculation of Water Drop Trajectories To and About Three-Dimensional Lifting and Non-lifting Bodies In Potential Airflow," NASA CR-3935, October 1985.

2. Kim, J.J., "Particle Trajectory Computation on a 3-Dimensional Engine Inlet," NASA CR175023, January 1986.

3. Bidwell, C.S., and Potapczuk, M.G., "Users Manual for the NASA Lewis Three-Dimensional Ice Accretion Code (LEWICE3D)," NASA TM-105974, December 1993.

4. Nathman, J.K., 'ICE Particle Trajectory and Ice Accretion Program, User's Manual, Version 2.0," December 1992.

5. Farrel, D.M., Vittal, B.V.R., "Computer Simulation of Water Ingestion for the T800-LHT801 Engine Anti-Icing Analysis,” AIAA-96-2652.

6. Bidwell, C.S., "Collection Efficiency and Ice Accretion Calculations for a Boeing 737-300 Inlet," NASA TM-107347, October 1996.

7. Pinella, D., Garrison, P., "CMARC, Three-Dimensional Low Order Panel Code, Version 2.1," 1997.

8. Ashby, D.L., Dudley, M.R., Iguchi, S.K., "Development and Validation of an Advanced Low-Order Panel Method," NASA TM-101024, October 1988.

9. Maskew, B., "Program VSAERO Theory Document: A Computer Program for Calculating Nonlinear Aerodynamic Characteristics of Arbitrary Configurations, "NASA CR-4023, September 1987.

10. Johnson, F.T., Samant, S.S., Bieterman, M.B., Melvin, R.G., Young, D.P., Bussoletti, J.E., and Hilmes, C.L., "TranAir: A Full-Potential, Solution-Adaptive, Rectangular Grid Code for Predicting Subsonic, Transonic, and Supersonic Flows About Arbitrary Configurations," NASA CR-4348, December 1992.

11. Krogh, F.T., "Variable Order Integrators for Numerical Solutions of Ordinary Differential Equations," Jet Propulsion Lab Technology Utilization Document No. CP-32308, November 1970.

12. Ruff, G.A., Berkowitz, B.M., "Users manual for the NASA Lewis Ice Accretion Prediction Code (LEWICE),” NASA CR-185129, May 1990.

13. Wright, W.B., "Users manual for the Improved NASA Lewis Ice Accretion Code LEWICE 1.6,” NASA CR-198355, June1995. 
14. Reehorst, A., Potapczuk, M., Ratvasky, T., and Gile Laflin, B., "Wind Tunnel Measured Effects on a Twin-Engine Short-Haul Transport Caused by Simulated Ice Accretions," AIAA-96-0871, NASA TM-107143, January 1996.

15. Reehorst, A., Potapczuk, M., Ratvasky, T., and Gile Laflin, B., "Wind Tunnel Measured Effects on a Twin-Engine Short-Haul Transport Caused by Simulated Ice Accretions, Data Report," NASA TM-107419, May 1997. 


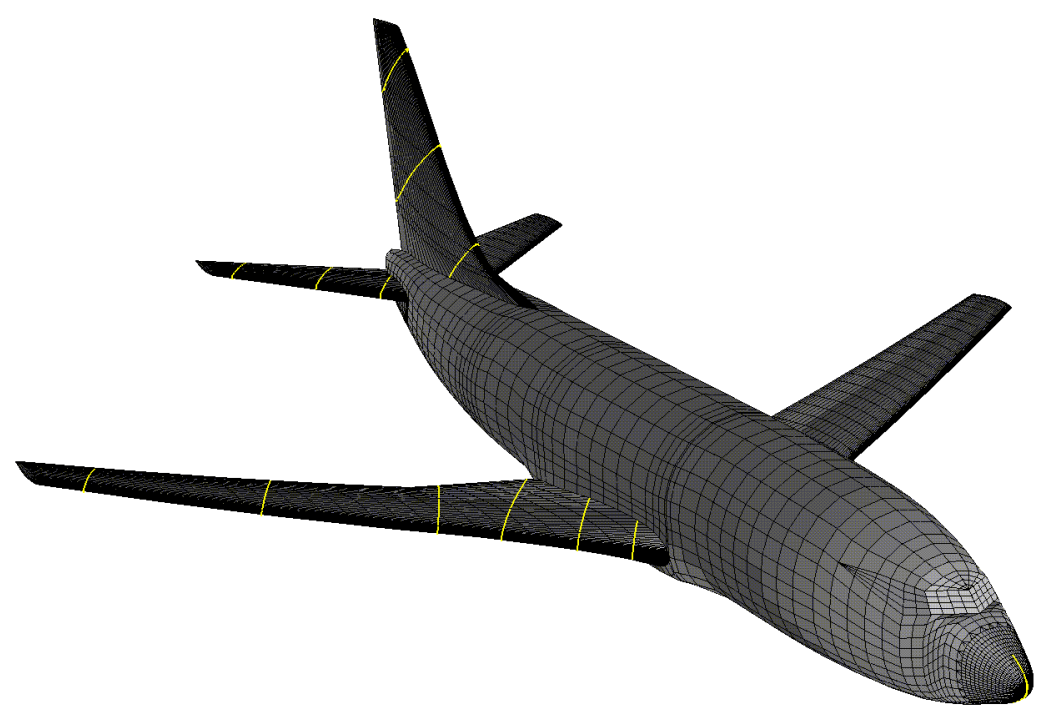

Figure 1. - CMARC panel model and sections-of-interest.

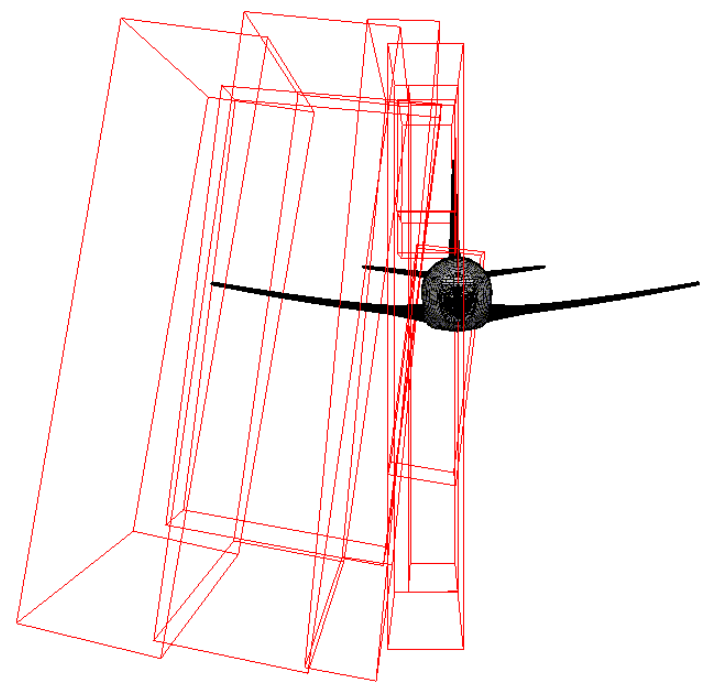

(a) Front view.

Figure 2. - CMARC panel model and ICEGRID3D grid block structure. 


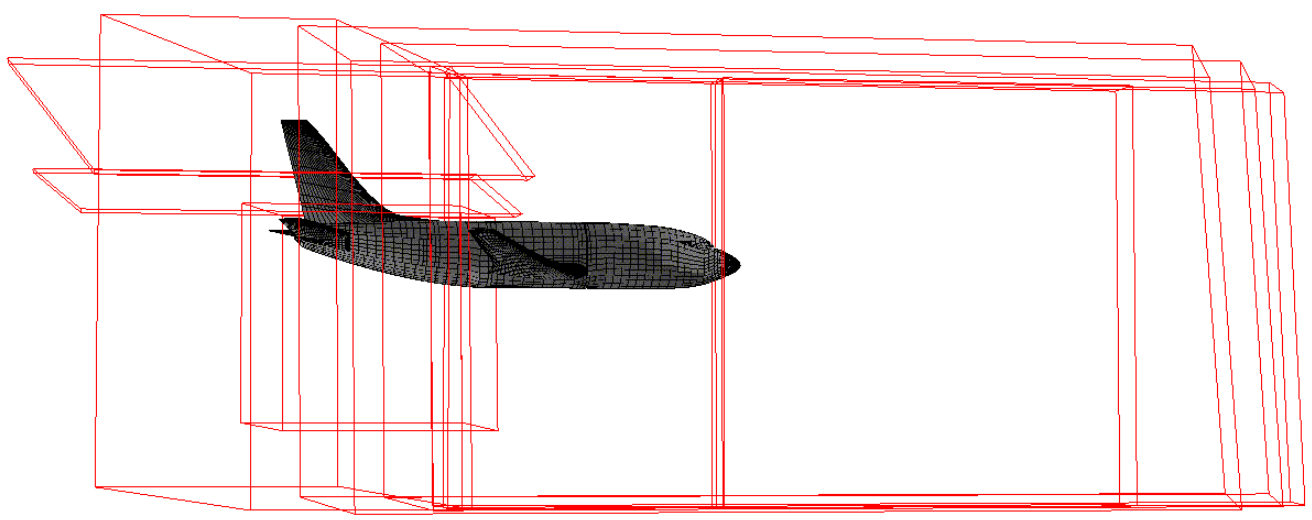

(b) Side view.

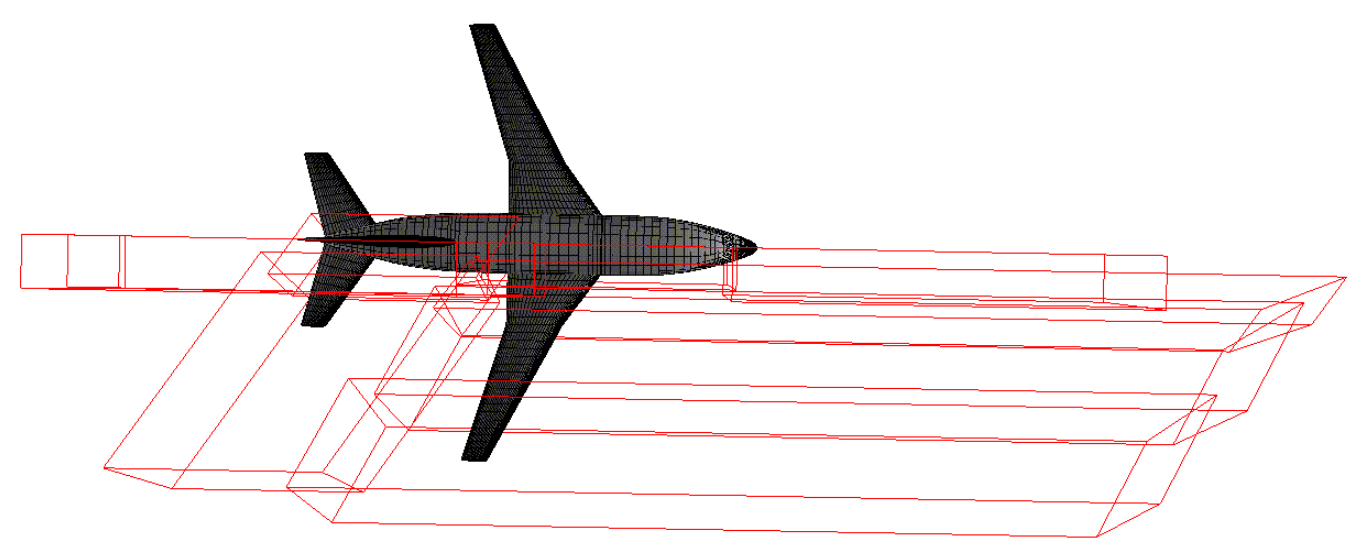

(c) Bottom view.

Figure 2. - Concluded. CMARC panel model and ICEGRID3D grid block structure. 


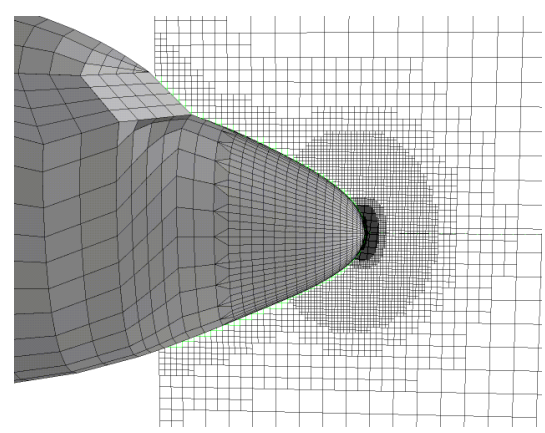

(a) Fuselage Nose.

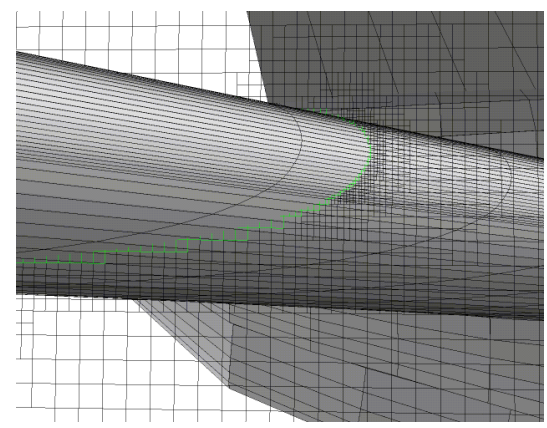

(c) Horizontal tail.

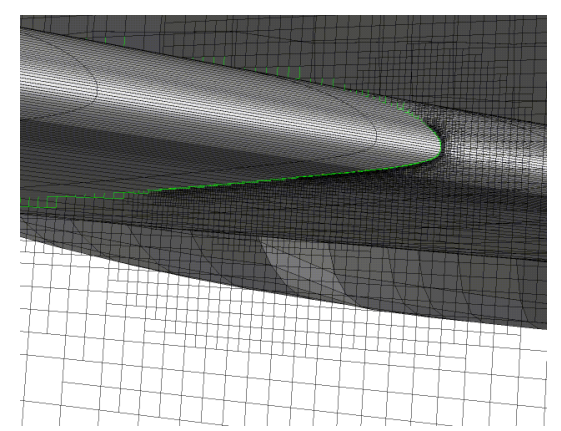

(b) Wing.

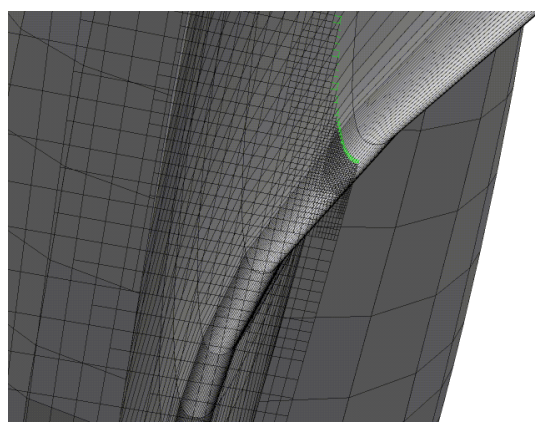

(d) Vertical tail.

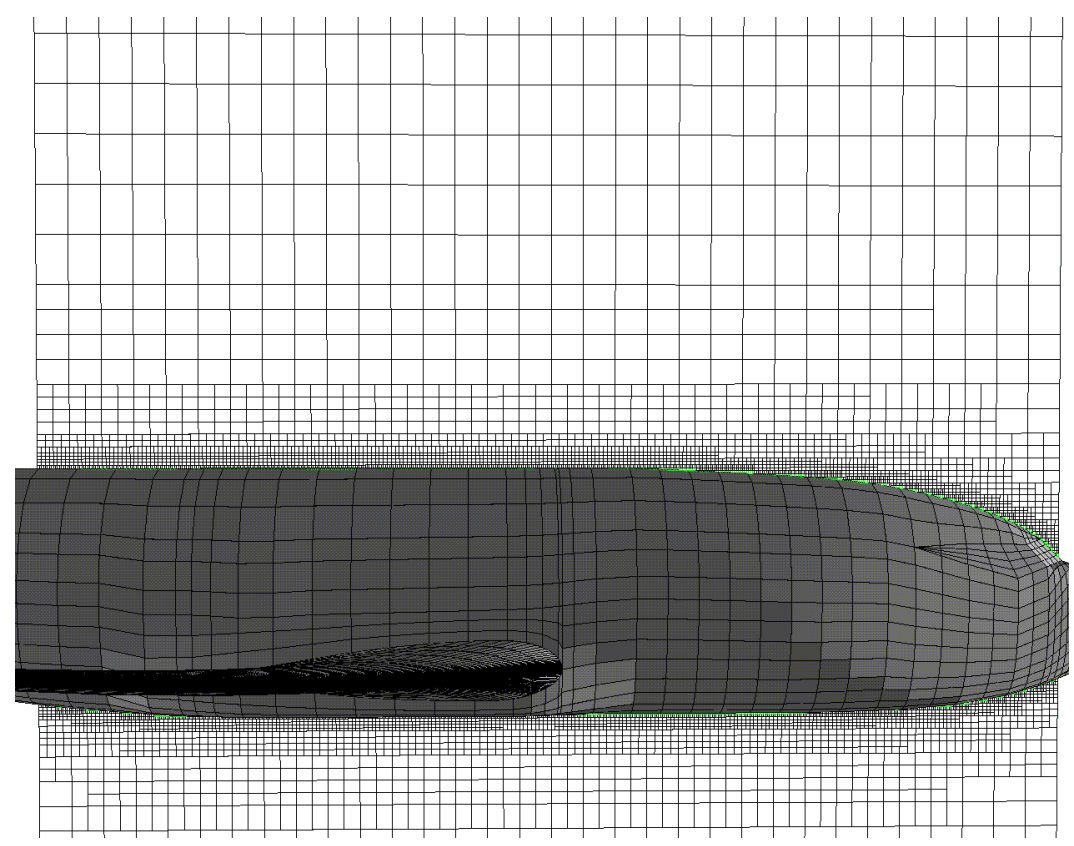

(e) Side view of fuselage.

Figure 3. - CMARC panel model and ICEGRID3D grid structure. 


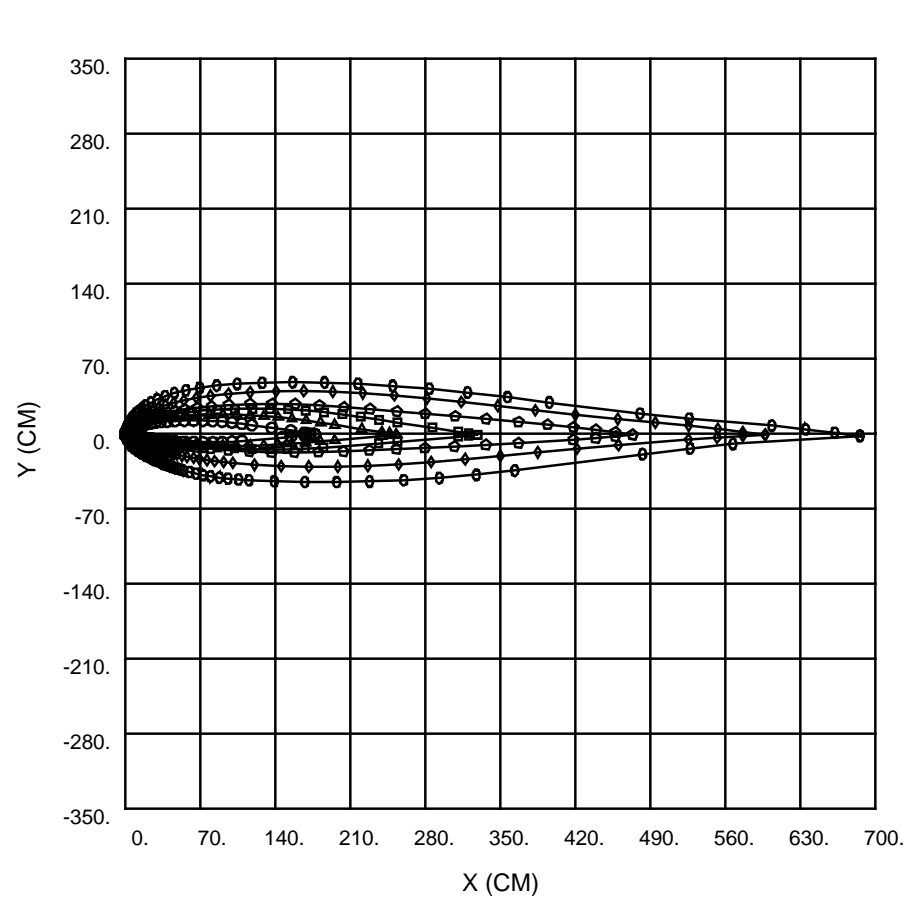

SPANWISE LOCATION: $y / b$

$\begin{array}{r}-.93 \\ -\quad .64 \\ \hline\end{array}$

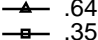

$\rightarrow .25$

$\rightarrow .13$

$\rightarrow .03$

Figure 4. - Wing profile at several span-wise stations.

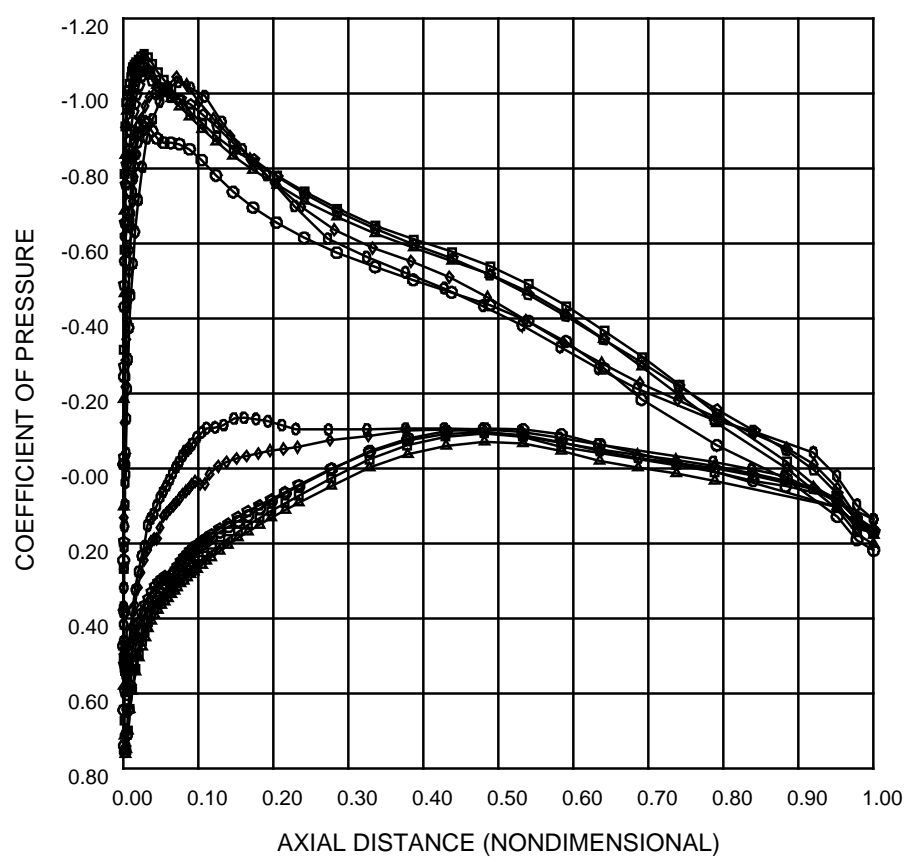

SPANWISE LOCATION: $y / b$

$\rightarrow .93$

$\rightarrow-.35$

$\rightarrow .25$

$\rightarrow .13$

$\rightarrow .03$

Figure 5. - Coefficient of pressure for wing at several span-wise stations for aircraft-angle-ofattack, 4 degrees. 


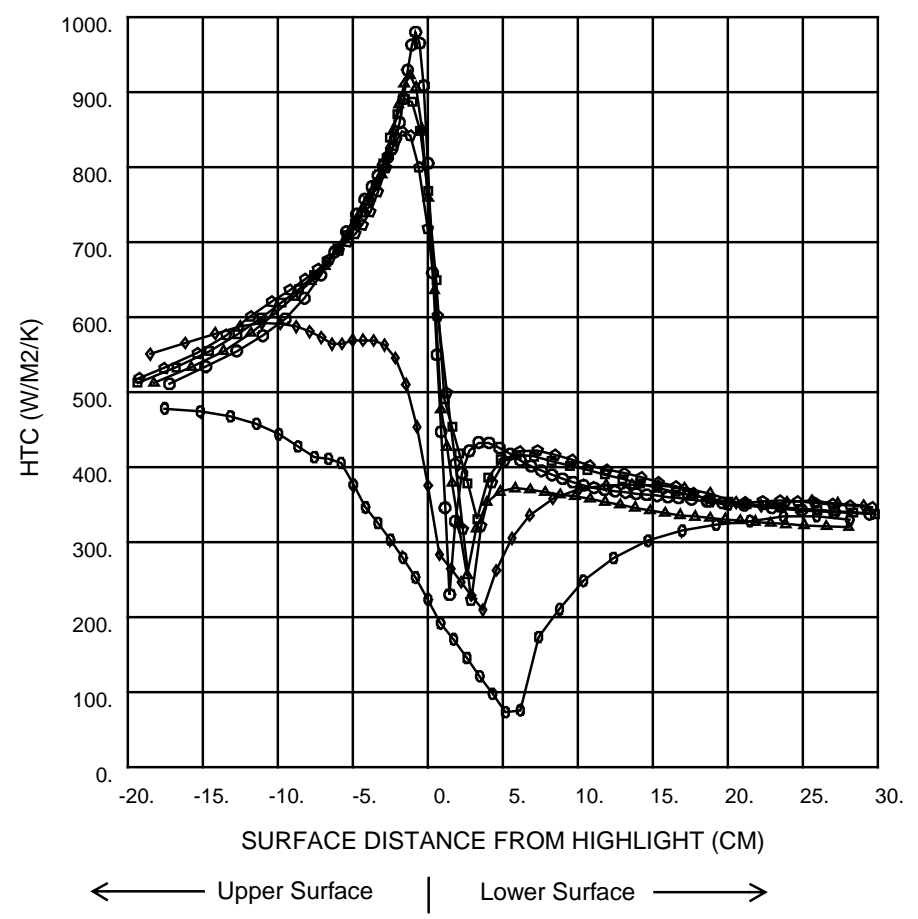

SPANWISE LOCATION: $y / b$

$$
\begin{aligned}
& \square .93 \\
& \rightarrow-.64 \\
& \square-.35 \\
& \square-.25 \\
& \square-.13 \\
& \square-.03
\end{aligned}
$$

Figure 6. - Analytical heat transfer coefficient distribution for the wing at several span-wise stations. Flight conditions; airspeed, $135 \mathrm{~m} / \mathrm{s}$; aircraft-angle-of-attack, 4 degrees; drop size, $20 \mu \mathrm{m}$; static temperature, $-14^{\circ} \mathrm{C}$; static pressure, $57800 \mathrm{~Pa}$.

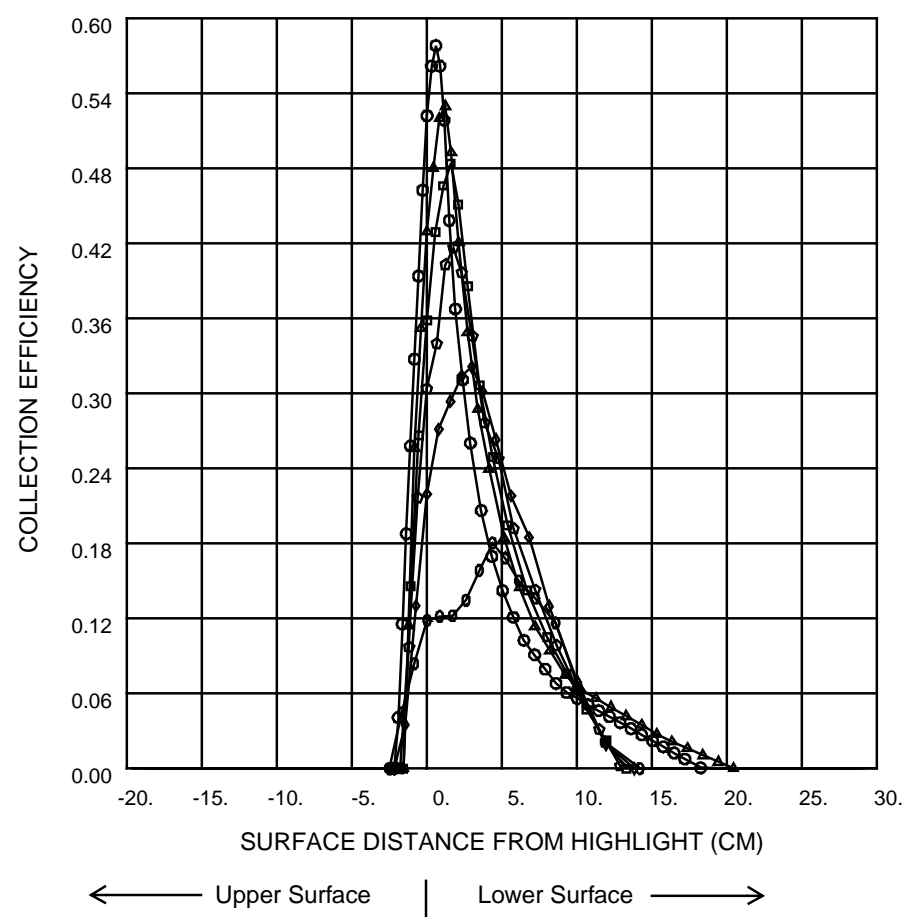

SPANWISE LOCATION: y/b

-.93
-.64

$\rightarrow .35$

$\multimap .25$

$\rightarrow .13$

$\rightarrow .03$

Figure 7. - Analytical collection efficiency distribution for the wing at several span-wise stations. Flight conditions; airspeed, $135 \mathrm{~m} / \mathrm{s}$; aircraft-angle-of-attack, 4 degrees; drop size, $20 \mu \mathrm{m}$; static temperature, $-14^{\circ} \mathrm{C}$; static pressure, $57800 \mathrm{~Pa}$. 


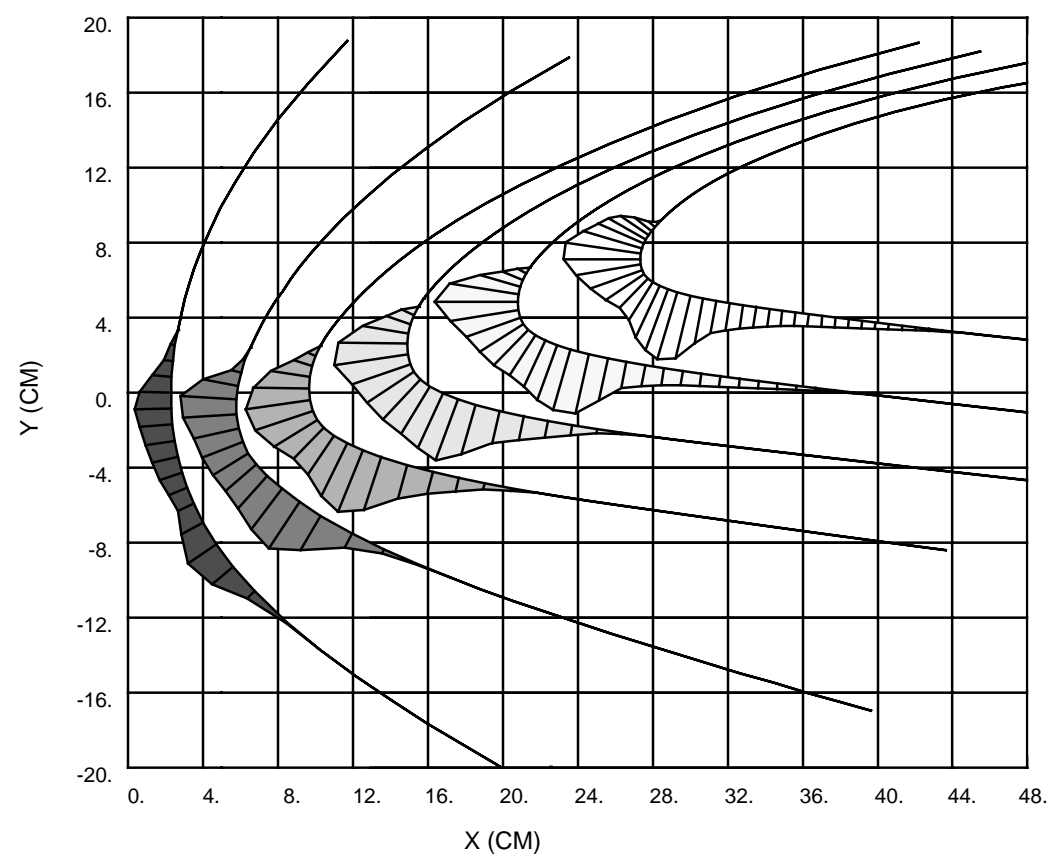

SPANWISE LOCATION: $\mathrm{y} / \mathrm{b}$

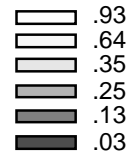

Figure 8. - Calculated ice accretions for the wing at several span-wise stations. Flight conditions; airspeed, $135 \mathrm{~m} / \mathrm{s}$; aircraft-angle-of-attack, 4 degrees; drop size, $20 \mu \mathrm{m}$; static temperature, $-14^{\circ} \mathrm{C}$; static pressure, $57800 \mathrm{~Pa}$.

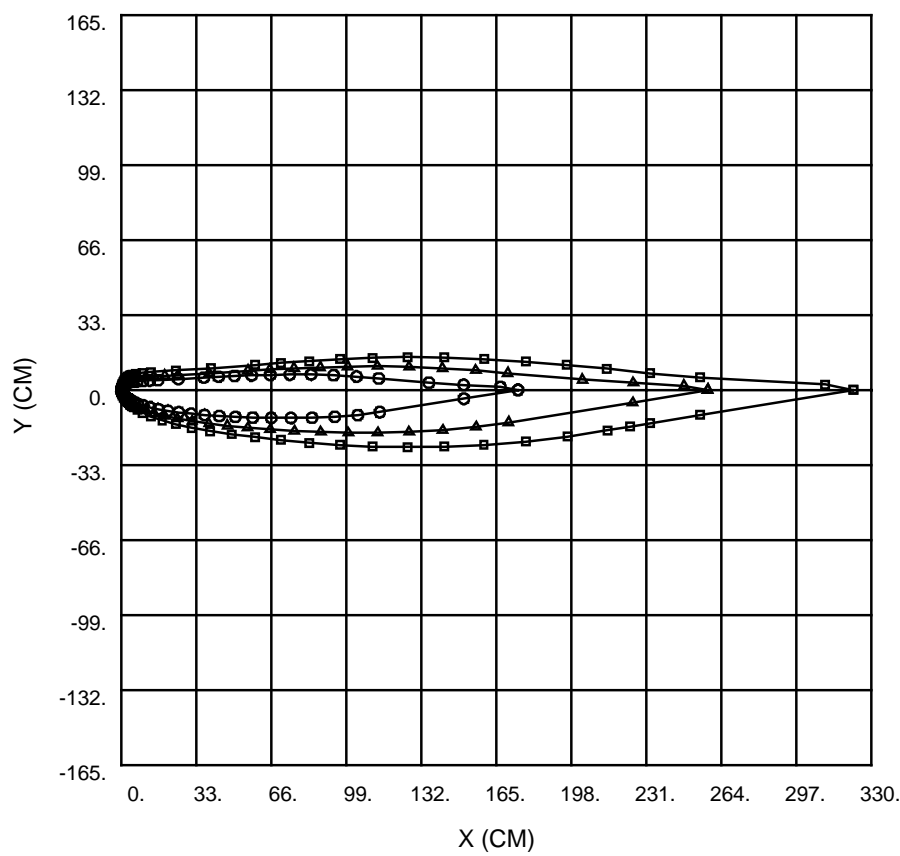

SPANWISE LOCATION: $y / b$

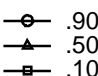

Figure 9. - Horizontal tail section profiles at several span-wise stations. 


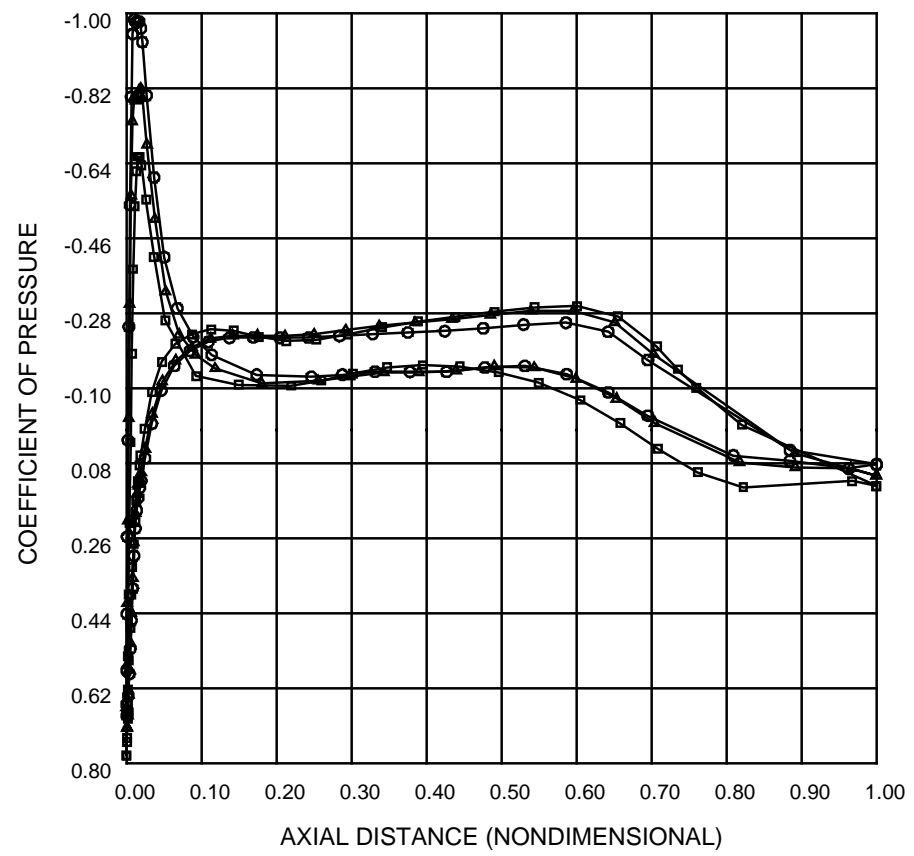

SPANWISE LOCATION: y/b

$\simeq .90$

$\leftarrow .10$

Figure 10. - Coefficient of pressure for horizontal tail at several span-wise stations for aircraftangle-of-attack, 4 degrees.

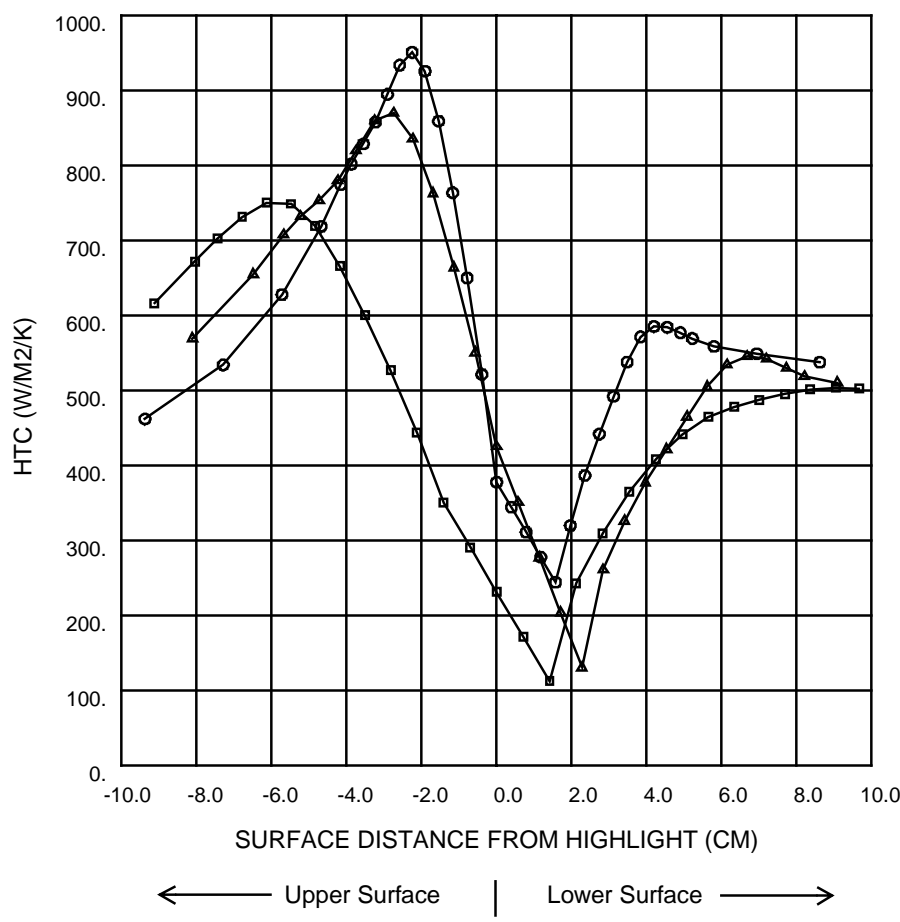

SPANWISE LOCATION: $y / b$

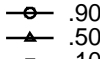

$\underset{\square-.50}{\square} .10$

Figure 11. - Analytical heat transfer coefficient distribution for the horizontal tail at several spanwise stations. Flight conditions; airspeed, $135 \mathrm{~m} / \mathrm{s}$; aircraft-angle-of-attack, 4 degrees; drop size, $20 \mu \mathrm{m}$; static temperature, $-14^{\circ} \mathrm{C}$; static pressure, $57800 \mathrm{~Pa}$. 


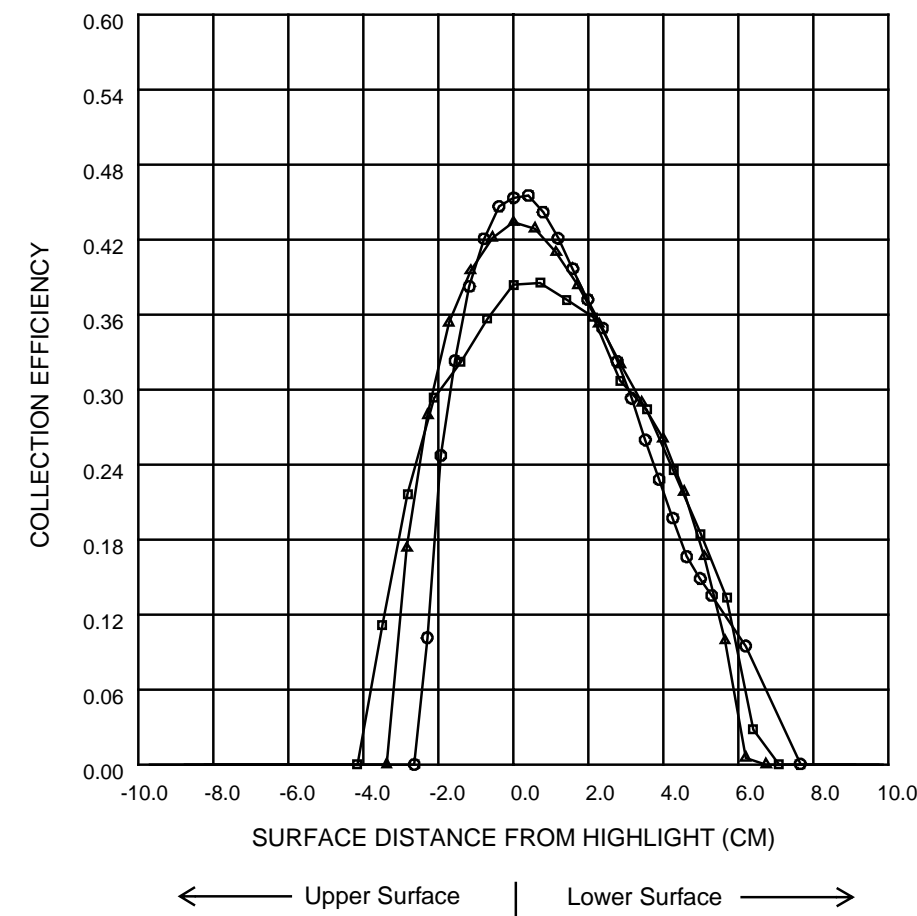

SPANWISE LOCATION: y/b

$\because .90$
$\rightarrow .50$
$\square .10$

Figure 12. - Analytical collection efficiency distribution for the horizontal tail at several span-wise stations. Flight conditions; airspeed, $135 \mathrm{~m} / \mathrm{s}$; aircraft-angle-of-attack, 4 degrees; drop size, $20 \mu \mathrm{m}$; static temperature, $-14^{\circ} \mathrm{C}$; static pressure, $57800 \mathrm{~Pa}$.

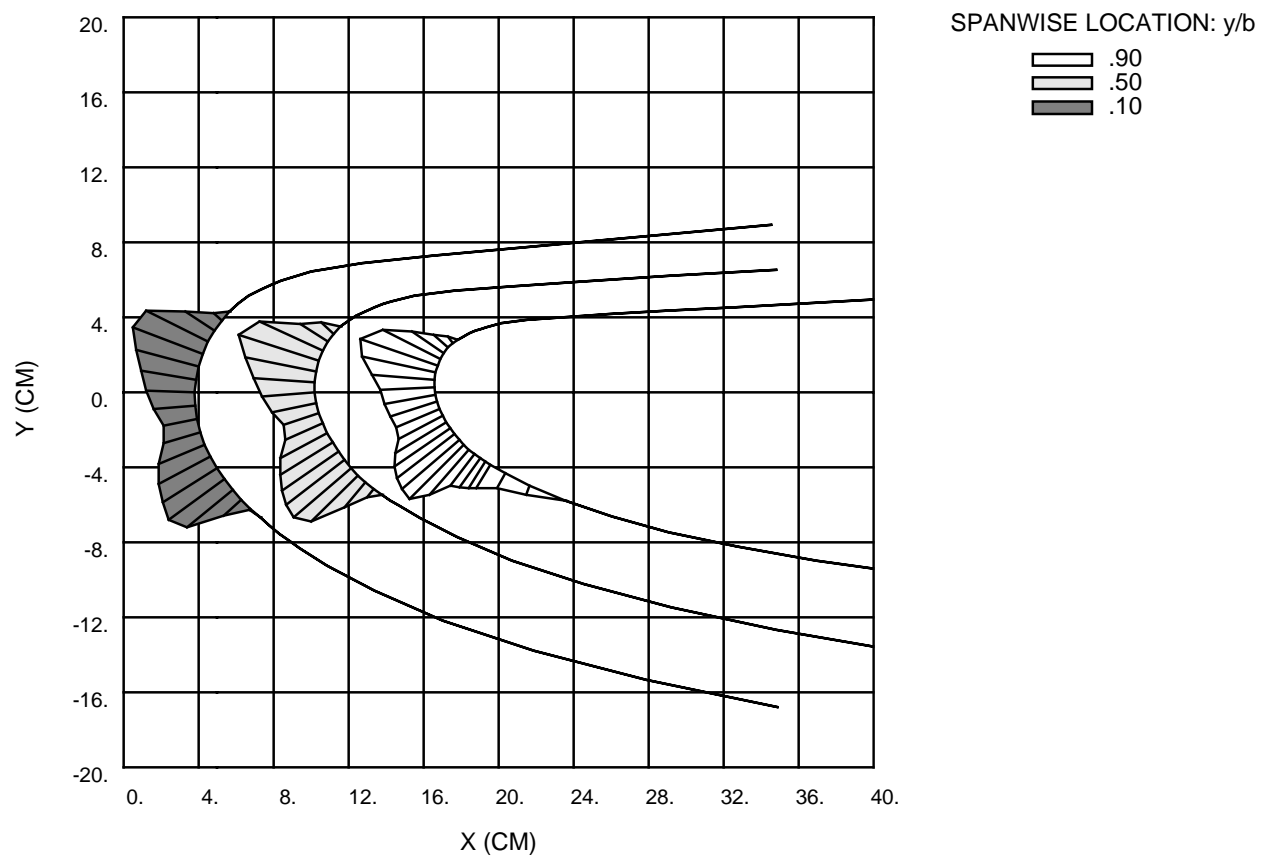

Figure 13. - Calculated ice accretions for the horizontal tail at several span-wise stations. Flight conditions; airspeed, $135 \mathrm{~m} / \mathrm{s}$; aircraft-angle-of-attack, 4 degrees; drop size, $20 \mu \mathrm{m}$; static temperature, $-14^{\circ} \mathrm{C}$; static pressure, $57800 \mathrm{~Pa}$. 


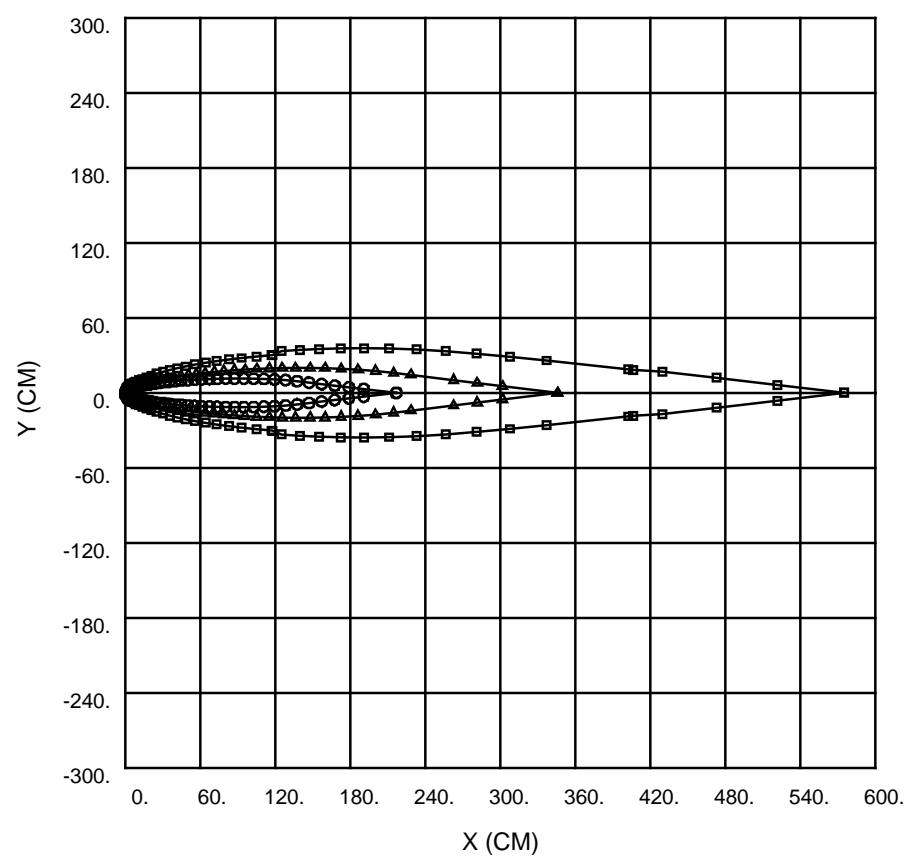

SPANWISE LOCATION: $y / b$

$\because .90$
$\simeq .50$
$\longrightarrow .10$

Figure 14. - Vertical tail section profiles at several span-wise stations.

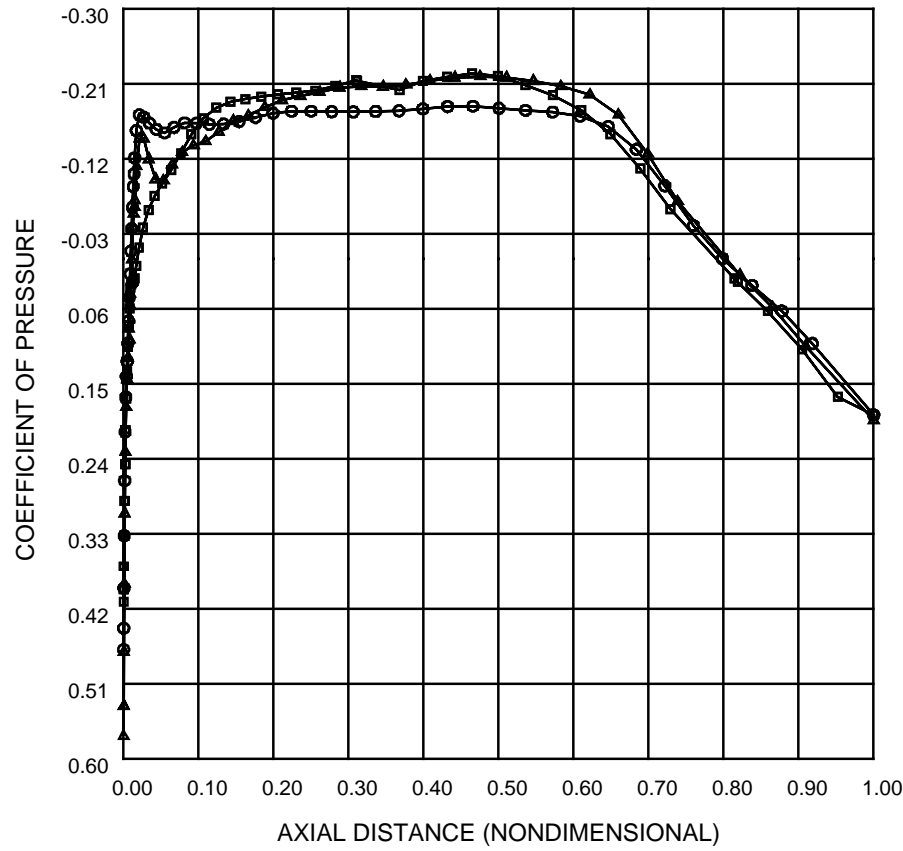

SPANWISE LOCATION: $y / b$

$\square .90$
$\square .50$
$\square . .10$

Figure 15. - Coefficient of pressure for vertical tail at several span-wise stations for aircraft-angleof-attack, 4 degrees. 


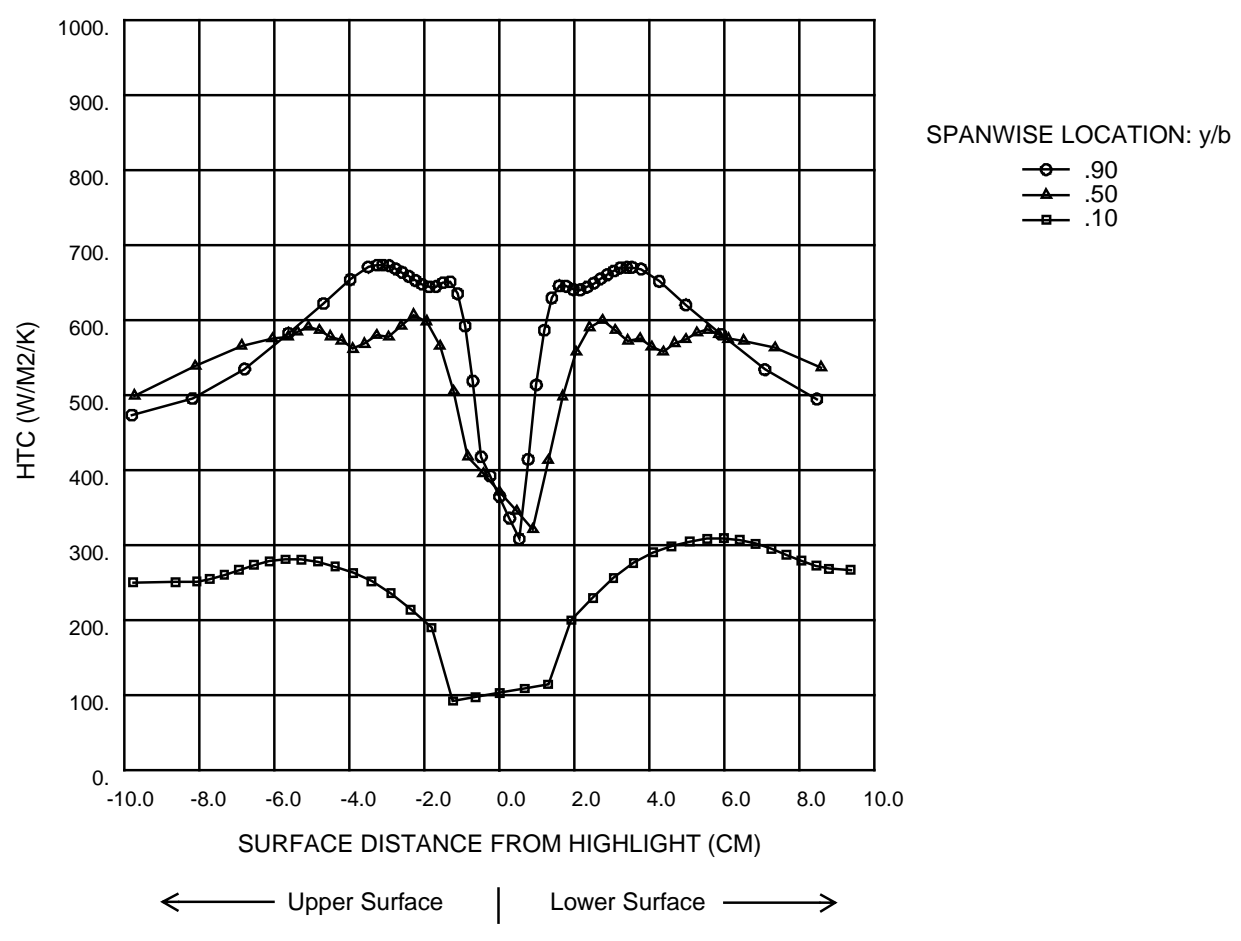

Figure 16. - Analytical heat transfer coefficient distribution for the vertical tail at several spanwise stations. Flight conditions; airspeed, $135 \mathrm{~m} / \mathrm{s}$; aircraft-angle-of-attack, 4 degrees; drop size, $20 \mu \mathrm{m}$; static temperature, $-14^{\circ} \mathrm{C}$; static pressure, $57800 \mathrm{~Pa}$.

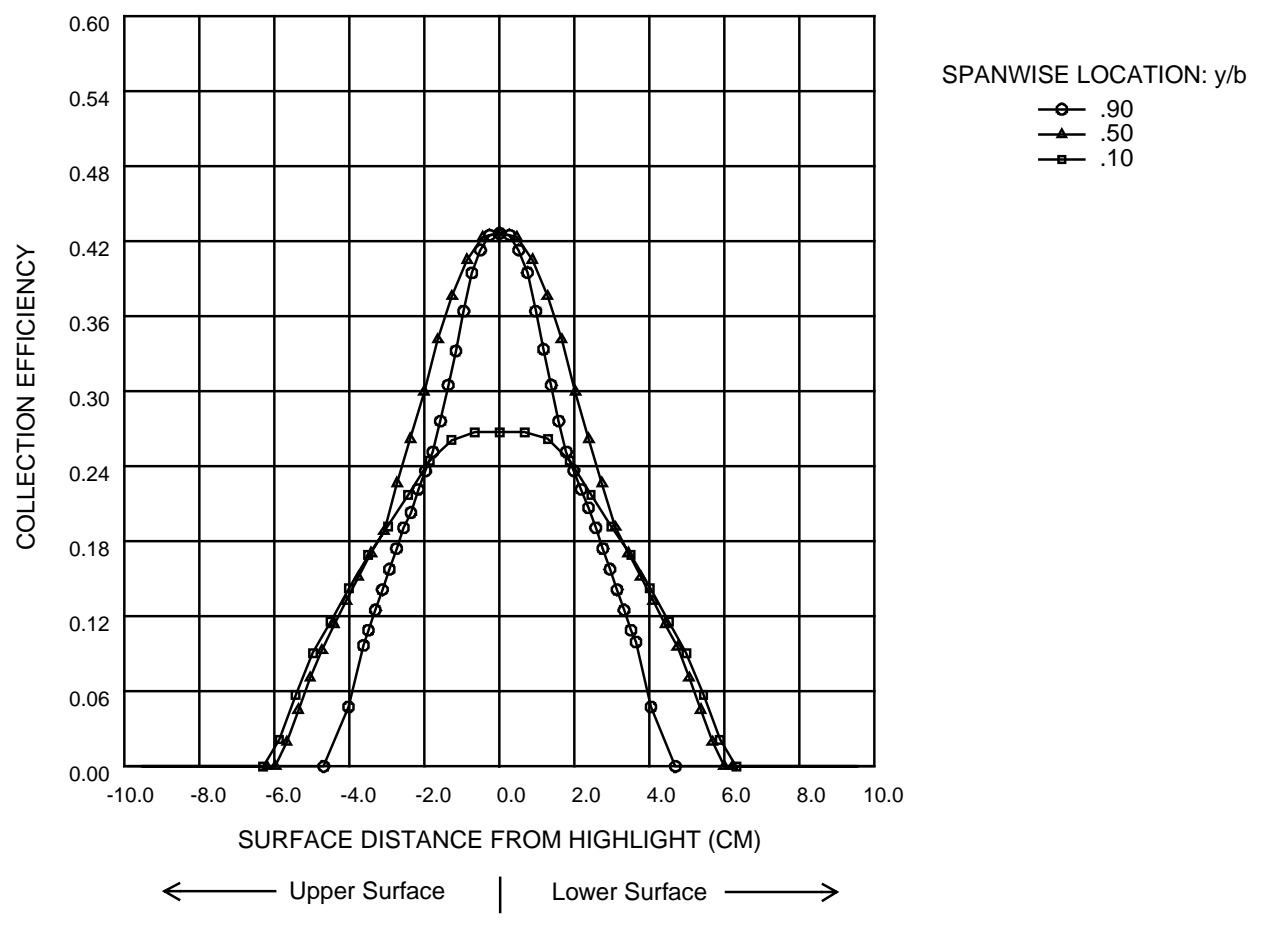

Figure 17. - Analytical collection efficiency distribution for the vertical tail at several span-wise stations. Flight conditions; airspeed, $135 \mathrm{~m} / \mathrm{s}$; aircraft-angle-of-attack, 4 degrees; drop size, $20 \mu \mathrm{m}$; static temperature, $-14^{\circ} \mathrm{C}$; static pressure, $57800 \mathrm{~Pa}$. 


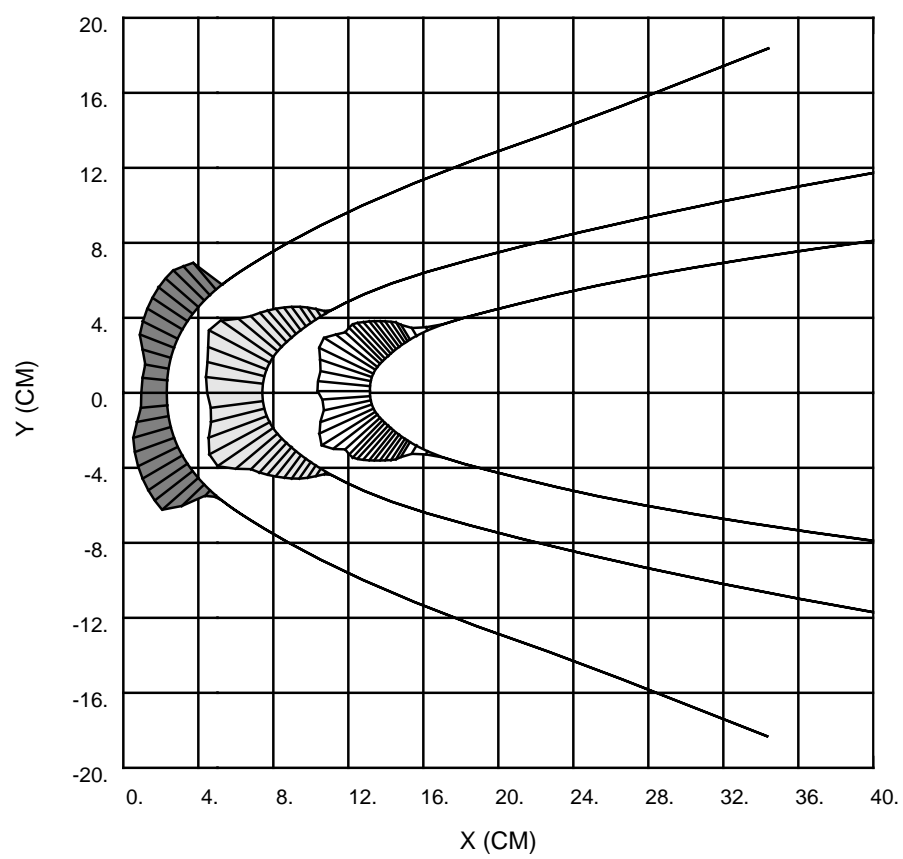

SPANWISE LOCATION: $y / b$

.90
$\square$
$\square$
$\square$
$\square$

Fgure 18. - Calculated ice accretions for the vertical tail at several span-wise stations. Flight conditions; airspeed, $135 \mathrm{~m} / \mathrm{s}$; aircraft-angle-of-attack, 4 degrees; drop size, $20 \mu \mathrm{m}$; static temperature, $-14^{\circ} \mathrm{C}$; static pressure, $57800 \mathrm{~Pa}$.

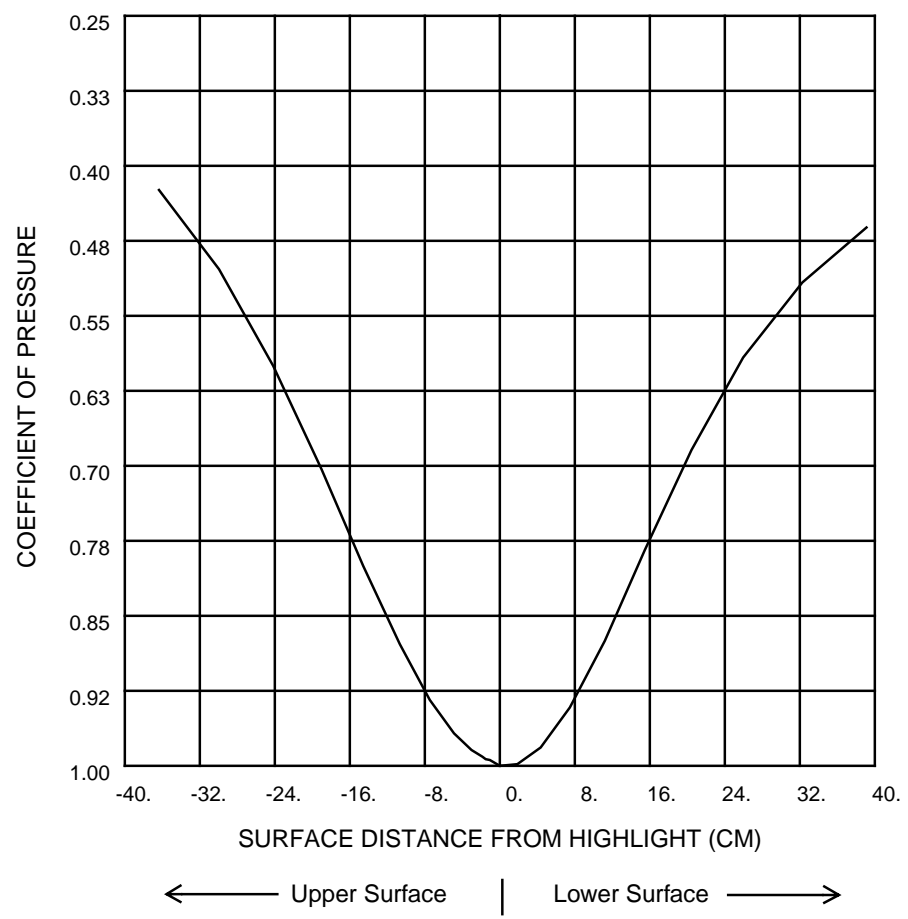

Figure 19. - Coefficient of pressure for fuselage nose for aircraft-angle-of-attack, 4 degrees. 


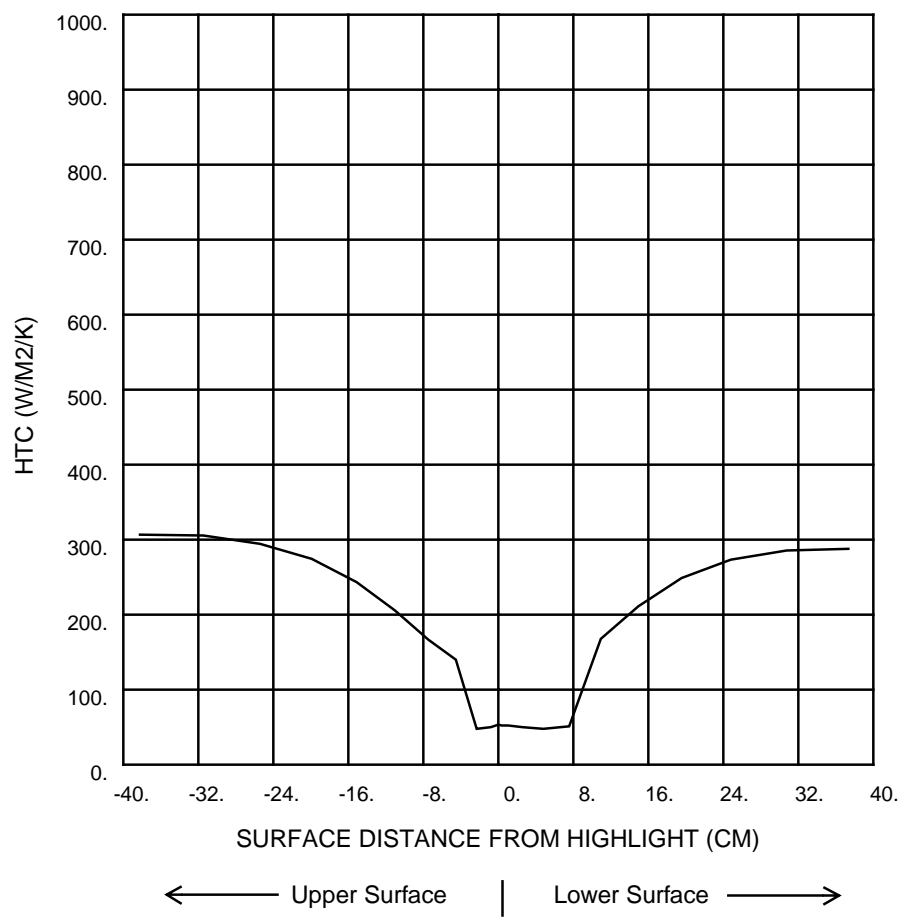

Figure 20. - Analytical heat transfer coefficient distribution for the fuselage nose. Flight conditions; airspeed, $135 \mathrm{~m} / \mathrm{s}$; aircraft-angle-of-attack, 4 degrees; drop size, $20 \mu \mathrm{m}$; static temperature, $-14^{\circ} \mathrm{C}$; static pressure, $57800 \mathrm{~Pa}$.

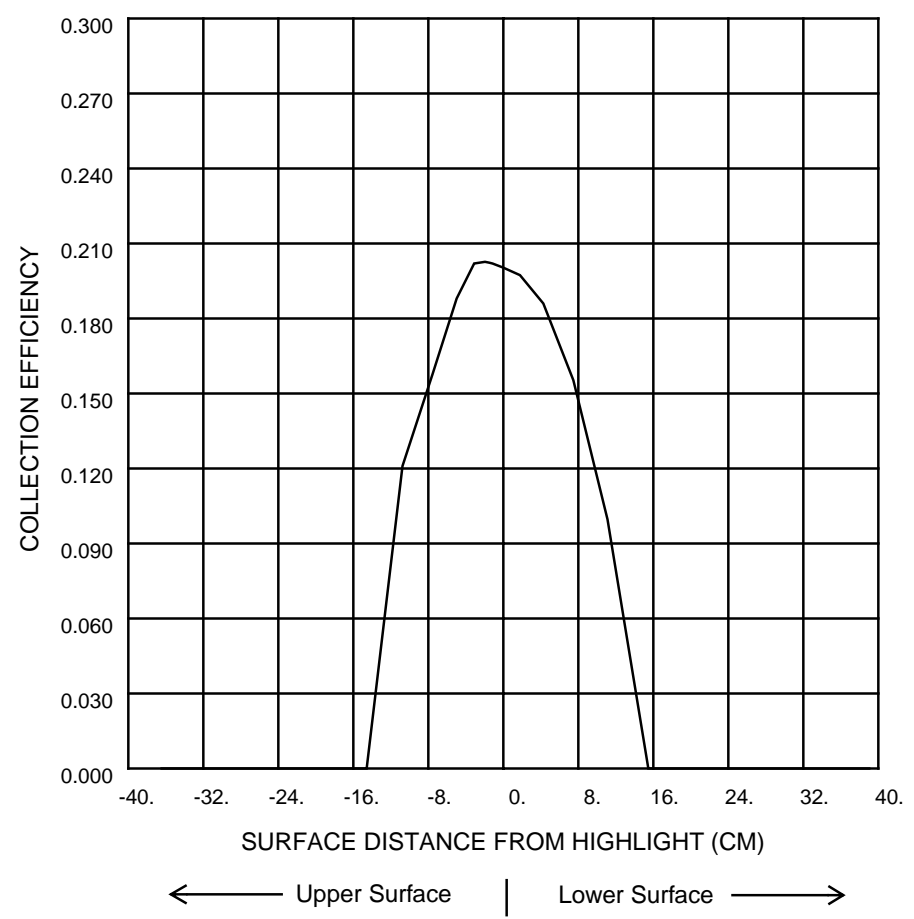

Figure 21. - Analytical collection efficiency distribution for the fuselage nose. Flight conditions; airspeed, $135 \mathrm{~m} / \mathrm{s}$; aircraft-angle-of-attack, 4 degrees; drop size, $20 \mu \mathrm{m}$; static temperature, $-14^{\circ} \mathrm{C}$; static pressure, $57800 \mathrm{~Pa}$. 


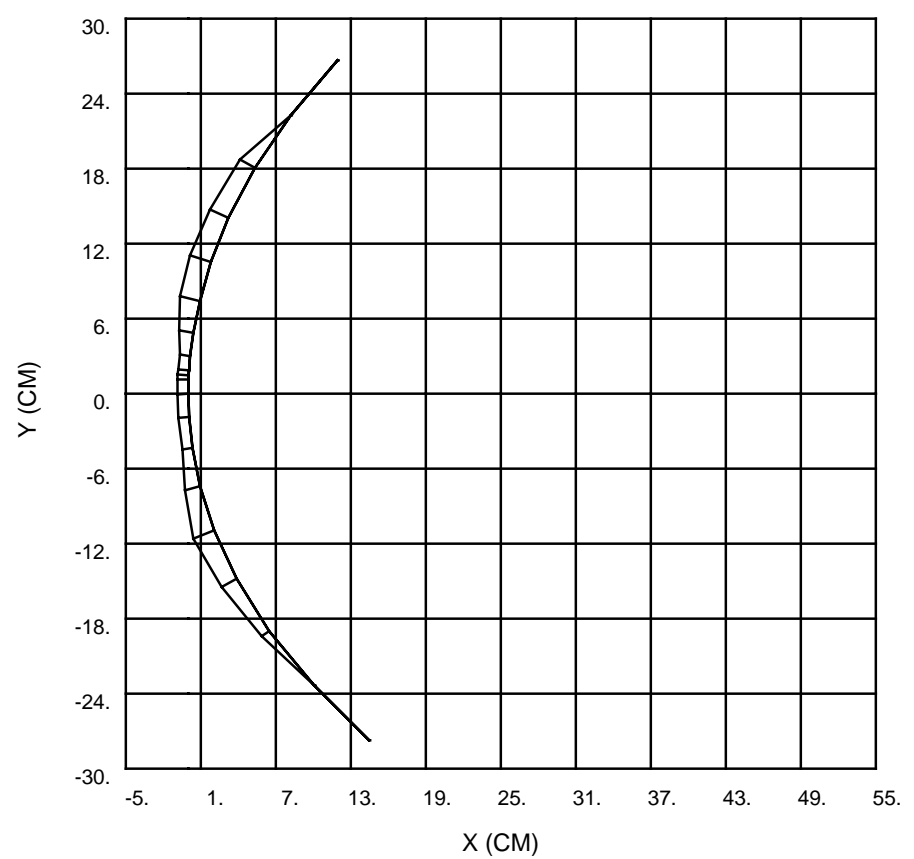

Figure 22. - Calculated ice accretions for the fuselage nose. Flight conditions; airspeed, $135 \mathrm{~m} / \mathrm{s}$; aircraft-angle-of-attack, 4 degrees; drop size, $20 \mu \mathrm{m}$; static temperature, $-14^{\circ} \mathrm{C}$; static pressure, $57800 \mathrm{~Pa}$.

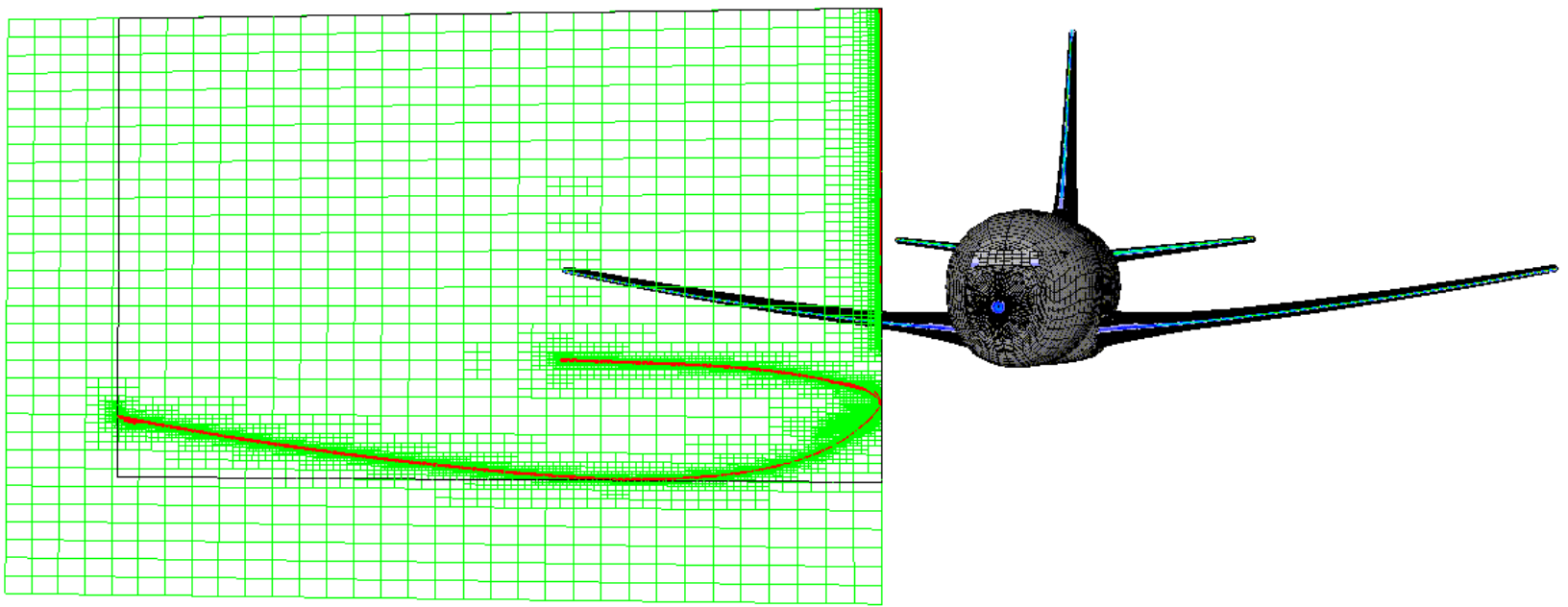

(a) Full aircraft with trajectory release points.

Figure 23. - Unstructured collection efficiency calculation for aircraft. Flight conditions; airspeed, $135 \mathrm{~m} / \mathrm{s}$; aircraft-angle-of-attack, 4 degrees; drop size, $20 \mu \mathrm{m}$; static temperature, $-14^{\circ} \mathrm{C}$; static pressure, $57800 \mathrm{~Pa}$. 


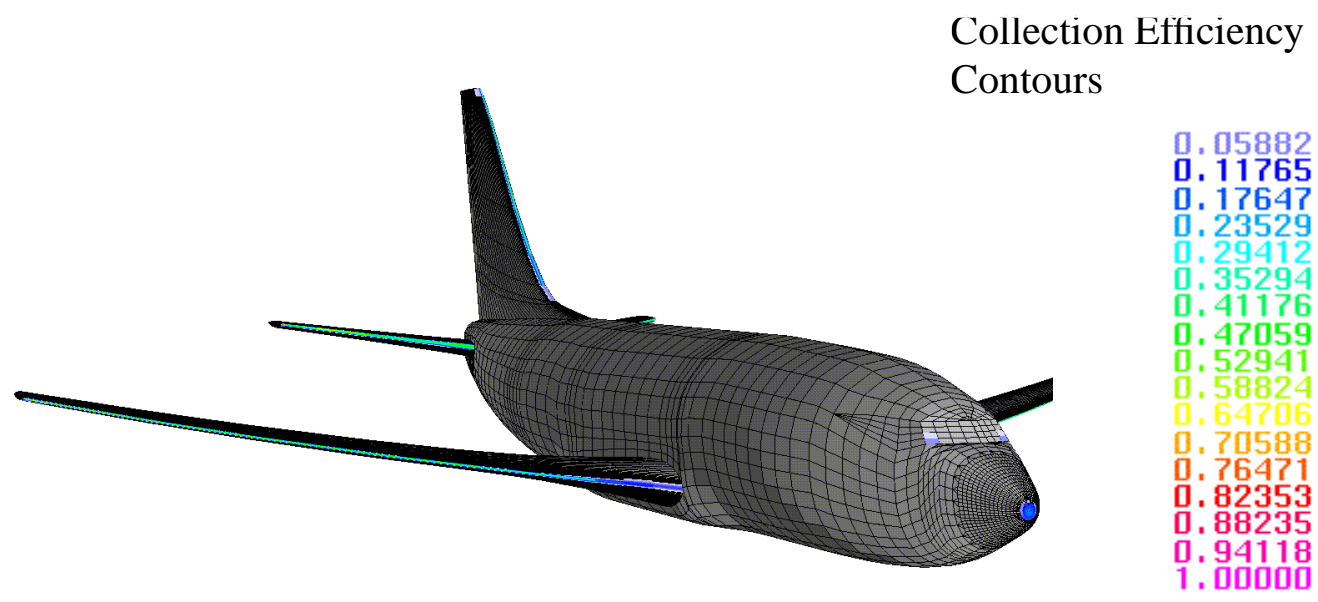

(b) Full aircraft.

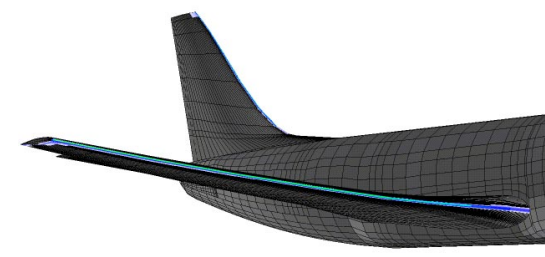

(c) Wing.

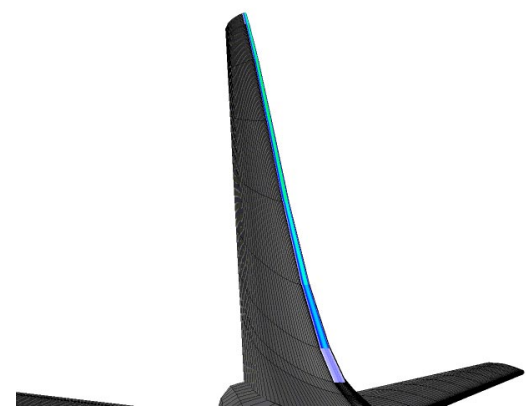

(e) Vertical tail.

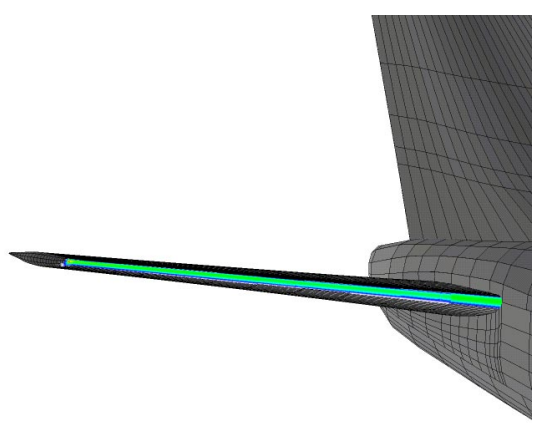

(d) Horizontal tail.

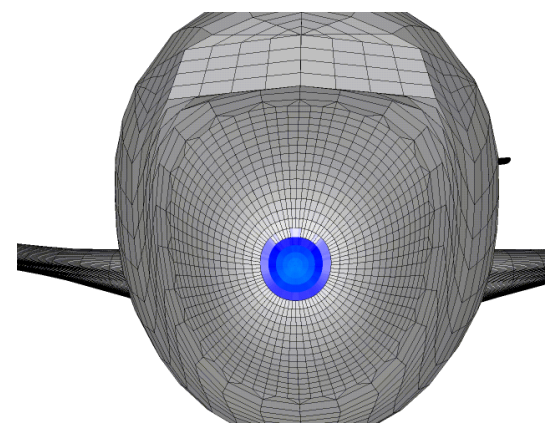

(f) Fuselage nose.

Figure 23. - Concluded. Unstructured collection efficiency calculation for aircraft. Flight conditions; airspeed, $135 \mathrm{~m} / \mathrm{s}$; aircraft-angle-of-attack, 4 degrees; drop size, $20 \mu \mathrm{m}$; static temperature, $-14^{\circ} \mathrm{C}$; static pressure, $57800 \mathrm{~Pa}$. 


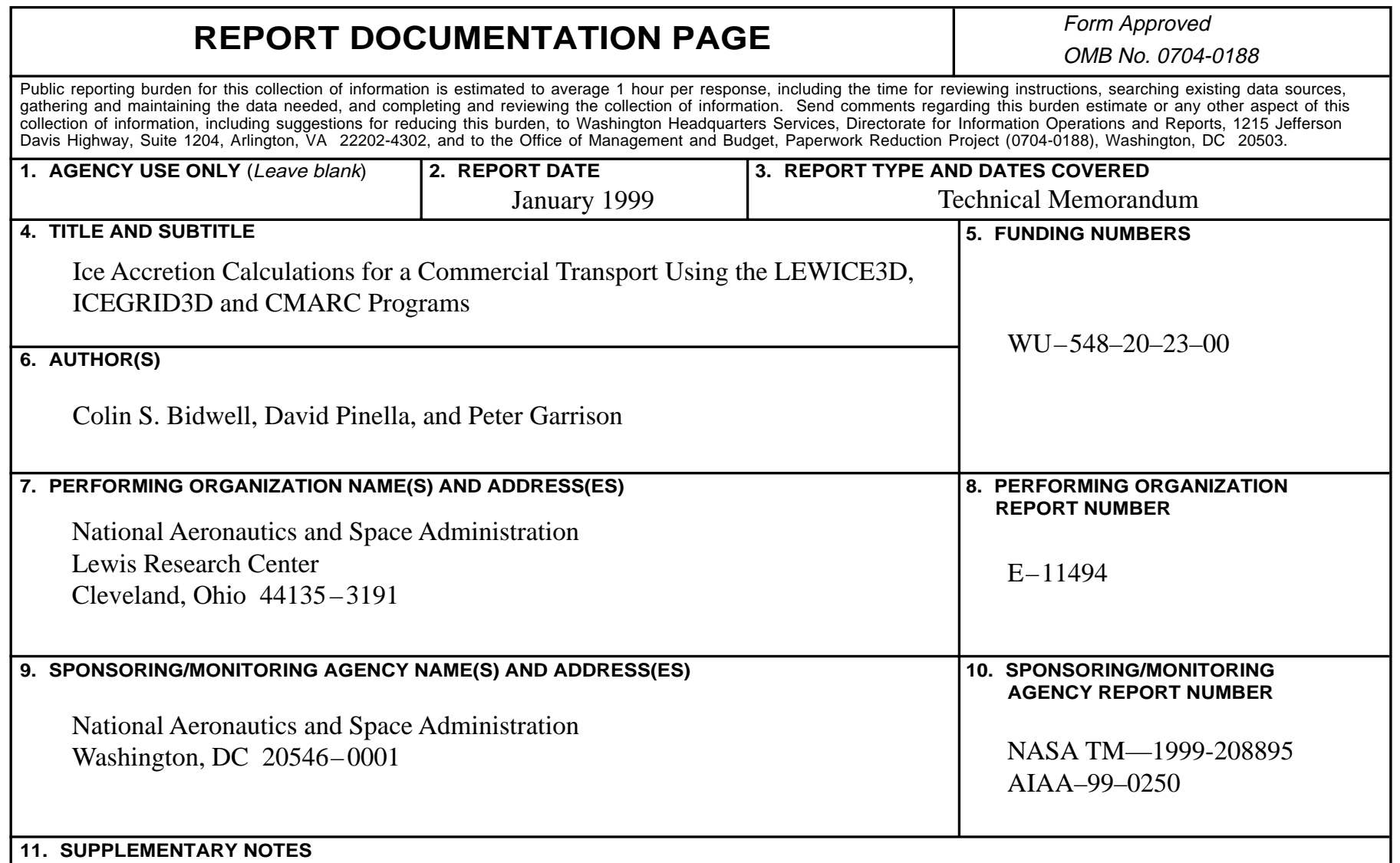

Prepared for the 37th Aerospace Sciences Meeting \& Exhibit sponsored by the American Institute of Aeronautics and Astronautics, Reno, Nevada, January 11-14, 1999. Colin S. Bidwell, NASA Lewis Research Center. David Pinella and Peter Garrison, AeroLogic, Los Angeles, California. Responsible person, Colin S. Bidwell, organization code 5840, (216) 433-3947.

\begin{tabular}{|l|l|l|l|l}
\hline 12a. DISTRIBUTION/AVAILABILITY STATEMENT & 12b. DISTRIBUTION CODE
\end{tabular}

Unclassified - Unlimited

Subject Categories: 01 and $34 \quad$ Distribution: Nonstandard

This publication is available from the NASA Center for AeroSpace Information, (301) 621-0390.

13. ABSTRACT (Maximum 200 words)

Collection efficiency and ice accretion calculations were made for a commercial transport using the NASA Lewis LEWICE3D ice accretion code, the ICEGRID3D grid code and the CMARC panel code. All of the calculations were made on a Windows 95 based personal computer. The ice accretion calculations were made for the nose, wing, horizontal tail and vertical tail surfaces. Ice shapes typifying those of a 30 minute hold were generated. Collection efficiencies were also generated for the entire aircraft using the newly developed unstructured collection efficiency method. The calculations highlight the flexibility and cost effectiveness of the LEWICE3D, ICEGRID3D, CMARC combination.

14. SUBJECT TERMS 15. NUMBER OF PAGES

Ice formation; Airplane; Ice accretion codes 33

\begin{tabular}{|c|c|c|}
\hline $\begin{array}{c}\text { 17. SECURITY CLASSIFICATION } \\
\text { OF REPORT } \\
\text { Unclassified }\end{array}$ & $\begin{array}{c}\text { 18. SECURITY CLASSIFICATION } \\
\text { OF THIS PAGE } \\
\text { Unclassified }\end{array}$ & $\begin{array}{c}\text { 19. SECURITY CLASSIFICATION } \\
\text { OF ABSTRACT } \\
\text { Unclassified }\end{array}$ \\
\hline
\end{tabular}

